Yayın Geliş Tarihi: 20.10.2020

Yayına Kabul Tarihi: 22.11.2020

Online Yayın Tarihi: 31.12.2020

http://dx.doi.org/10.16953/deusosbil.813341
Dokuz Eylül Üniversitesi

Sosyal Bilimler Enstitüsü Dergisi

Cilt: 22, Say1: 4, Y11: 2020, Sayfa: 1315-1346

ISSN: 1302-3284 E-ISSN: 1308-0911

Araştırma Makalesi

\title{
SMINTHEION BÜYÜK ROMA HAMAMI DAMGA BEZEMELİ GEÇ ROMA SERAMIKLERI
}

Onurcan YAVUZ*

$\ddot{\boldsymbol{O}} z$

Apollon Smintheion Kutsal Alani; Anadolu'nun kuzeybatısinda, Çanakkale ilinin Gülpınar köyünde yer almaktadır. Kutsal alanda 2008 yılında başlayan Büyük Roma Hamamı kazısı, 2011 yılında tamamlanmıştır. Burada ele geçen ve Geç Roma Dönemi'ne tarihlendirilen damga bezemeli seramikler çalışma konusunu oluşturmaktadır. Yapılan kazı çalışmaları sonucunda ortaya çıkarılmış yirmi dokuz adet damga bezemeli seramik çalışılmak üzere değerlendirmeye alınmıştır. Yapılan değerlendirmeler sonucunda bunların yirmi dört tanesinin Phokaia'da üretilen damgalılara, beş örneğin ise Afrika üretimi damga bezemeli seramikler olduğu anlaşılmıştır. Örneklerin repertuar çeșitliliğine bakıldığında; on tanesinin haç ve varyasyonlarına, sekiz tanesinin hayvan, beş tanesinin bitkisel, dört tanesinin geometrik ve iki tanesinin de insan damga bezemesi taşıdı̆̆ görülmektedir. Yapılan bu çalışma ile MS 4-6. yüzyıllar arasına tarihlendirilen damga bezemelilerin Batı Anadolu ve özelliklede Troas Bölgesi'ndeki diğer kentlerle olan ilişkilerine değinilerek hangi damga bezemelerin daha baskın olarak kullanıldiğı, bunların birbirleriyle olan benzerlik ve farklılıklarının ortaya çıkarılması amaçlanmaktadır.

Anahtar Kelimeler: Smintheion, Roma Hamamı, Roma Seramiği, Damga Bezeme

\section{LATE ROMAN POTTERY WITH STAMPED DECORATION OF SMINTHEION LARGE ROMAN BATHS}

\begin{abstract}
The Sanctuary of Apollon Smintheion is located in the Gülpınar village of Çanakkale in the northwest of Anatolia. The Great Roman Bath excavations started in 2008 in the sanctuary, were completed in 2011. The subject of this study is the stamp-decorated ceramics found in here and dated to the Late Roman period. Twenty-nine stamp-decorated ceramics founded in the excavations were evaluated for the study. As a result of the evaluations, it was

Bu makale için önerilen kaynak gösterimi (APA 6. Sürüm):

Yavuz, O. (2020). Smintheion Büyük Roma Hamamı damga bezemeli Geç Roma seramikleri. Dokuz Eylül Üniversitesi Sosyal Bilimler Enstitüsü Dergisi, 22 (4), 1315-1346

* Yüksek Lisans Öğrencisi, Ondokuz Mayıs Üniversitesi, Lisansüstü Eğitim Enstitüsü, Arkeoloji Anabilim Dal1, ORCID: 0000-0002-5889-2211 onurcan13yvz@gmail.com
\end{abstract}


understood that twenty-four of stamped ceramics produced in Phokaia workshops and five of stamp-decorated ceramics produced in Africa. Considering the repertoire diversity of the samples; it was understood that ten of them have cross and its variations, eight of them have animals, five of them have vegetative, four of them have geometric and two of them have human stamped decorations. In this study, it is aimed to reveal which stamped decorations are used more dominantly, and their similarities and differences with each other by referring to the relationships of the stamped decorations dated between the 4th and 6th centuries AD in Western Anatolia and especially with other cities in the Troas region.

Keywords: : Smintheion, Roman Bath, Roman Ceramics, Stamped Decoration

\section{GíRiș}

Apollon Smintheion Kutsal Alanı; Anadolu'nun kuzeybatısında, Biga Yarımadası'nın güneybatı köşesindeki Gülpınar köyünde yer almaktadır (Özgünel, 1982, ss. 207-208). Kutsal alanda 2008 yılında başlayan Büyük Roma Hamamı kazıları 2011 yılında tamamlanmıştır (Fig. 1). Burada ele geçen ve Geç Roma Dönemi'ne tarihlendirilen damga bezemeli bir grup seramik çalışma konusunu oluşturmaktadır. Form ve bezeme özellikleri bakımından nitelikli oldukları düşünülen toplam yirmi dokuz adet damga bezemeli seramik, çalışılmak üzere değerlendirmeye alınmıştır. Yapılan değerlendirmeler sonucunda bunların yirmi dört tanesinin Phokaia üretimi damgalılara, beş örneğin ise Afrika üretimi damga bezemeli seramikler olduğu anlaşılmıştır. Örneklerin repertuar çeşitliliğgine bakıldığında bunların; on tanesinin haç ve varyasyonlarına, sekiz tanesinin hayvan, beş tanesinin bitkisel, dört tanesinin geometrik ve iki tanesinin de insan damga bezemesi taşıdığı görülmektedir.

Figür 1: Büyük Roma Hamamı Hava Fotoğrafi

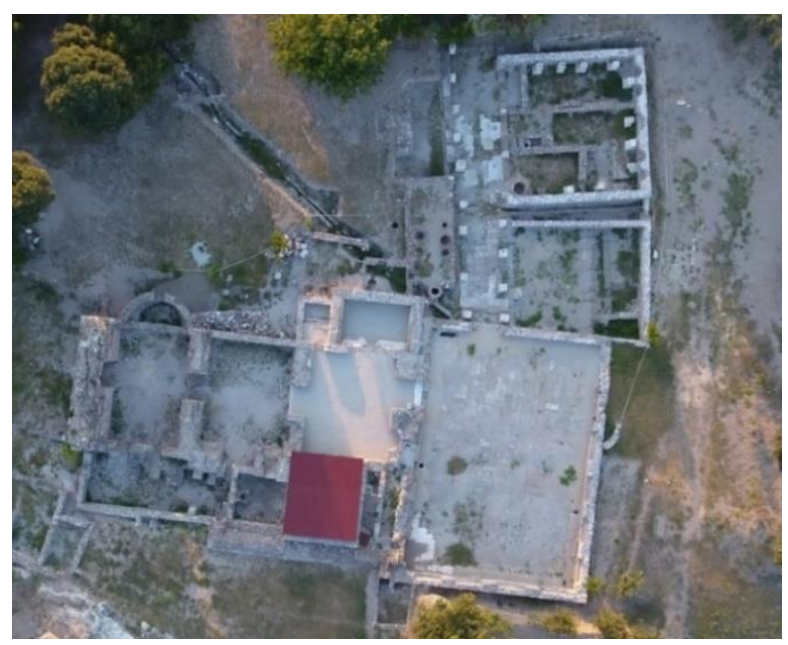

Kaynak: 2017 Smintheion Kazı Arşivi. 
Seramiklerin ele geçtiği Büyük Roma Hamamı’nın kullanımının MS 4. yüzyılın sonuna kadar sürdüğü ve bu tarihten sonra da hamam ve çevresinin konut ve işlik gibi farklı yapılara dönüştürüldüğü belirtilmektedir. MS 5-6. yüzyıl arasına tarihlendirilen çanak çömlekler ve tahıl işleme aletleri gibi buluntular, hamamın farklı bir yapıya dönüştürülerek yeniden kullanıldığını göstermektedir. (Kaplan, 2018, s. 35). Smintheion Kutsal Alanı'ndaki erken dönem yapıları incelendiğinde bunların tekrar tekrar kullanıldıkları ve zamanla yeni yapıların malzeme eksikliğinin giderilebilmesi için tahrip edildikleri bilinmektedir. (Koçyiğit, 2013, ss. 152-153). Genel olarak bakıldığında işlevini kaybeden ve kullanım ömrünü tamamlayan yapıların yeni yapılara dönüştürülmesi ve malzemenin bu yapılardan temin edilmesi dönemin şartları düşünüldüğünde son derece normal olmalıdır.

\section{AFRİKA GEÇ ROMA DAMGA BEZEMELİ SERAMİKLERİ}

Smintheion Roma Hamamı'nda 2008-2011 yılları arasında gerçekleştirilen kazı çalışmaları sırasında bulunan beş adet örnek, Afrika Geç Roma damga bezemeli seramikleri içerisinde değerlendirilmeye alınmıştır. 2008 yılında yapılan çalışmalarda ortaya çıkarılan Dört adet örneğin bir tanesi bitkisel (Kat. No. 1), bir tanesi hayvan (Kat. No. 2) ve iki tanesi de haç ve varyasyonlarına (Kat. No. 4-5) aittir. 2010 yılında bulunan insan figürlü bir örnekte (Kat. No. 3) çalışmaya dâhil edilmiştir.

Kat. No. 1; üzerinde bask1 tekniğiyle yapılmış iç içe geçmiş üç daire ile palmiye yaprağı bulunmaktadır. Hayes tarafindan A Stilinde değerlendirilen örnekte palmiye yaprağı ve üçlü konsantrik daire motifi kullanılmıştır. Konsantrik daire üç merkezlidir. Tarih olarak MS 4-5. yüzyıl arasına tarihlendirilir (Tab. 1). Benzerleri: Atina Agorası (Hayes, 1972, s. 229, Fig. 38: c: Hayes, 2008, S. 234, Plate 58: 1180), El Mahrine (Kuzey Tunus) (Mackensen, 1993, Tafel 26: 1, 3), Ptolemais (Domzalski, 2012, s. 337, Plate 8: 5-7) ve Leodikeia'da (Şimşek \& Bilgin, 2018, s. 181, Fig. 10) görülmektedir.

Kat. No. 2; neredeyse yarım küre şeklinde işlenmiş kasenin merkezinde bask1 tekniğiyle yapılmış bir hayvan figürü bulunmaktadır. Hayvan damgası muhtemelen kuzu olmalıdır ( Tab. 1). E (i) stili içerisinde değerlendirildiği için tarih olarak MS 480-540 aras1 verilir (Hayes, 1972, ss. 221-222). Benzerleri; Atina Agorast (Hayes, 1972, Fig. 48: 166-169), Anemurium (Williams, 1989, Plate 6: 259), ve Ptolemais'de (Domzalski, 2012, s. 337, Plate 8: 11) görülmektedir.

Kat. No. 3; birbirini tamamlayan iki parça halinde bulunan amorf parçanın merkezinde bir din adamı (Rahip) betimlenmiştir. Figürün sadece gövdeden aşağısı korunmakta olup üzerinde dalmatica giydiği görülmektedir. Figürün görülebilen sağ kolu gögüs boyunca bükülmüş olmalıdır. Muhtemelen bu kol ile bir asa üzerinde haç tutmaktadır. Ayaklarında sandalet bulunur (Tab. 2). Hayes tarafindan Stil E (ii) içerisinde değerlendirilmesinden dolayı MS 6 . yüzyılın ikinci yarısına 
tarihlendirilmiştir (Hayes, 1972, s. 265). Benzerleri Atina Agorası (Hayes, 1972, s. 266, Fig 51: 235 e) ve Tarsus'da (Adıbelli, 2006, s. 170, Lev. 12: 142) görülmektedir.

Kat. No. 4; dairesel yiv içerisinde kabın merkezinde baskı tekniğiyle yapılmış bir haç damgası işlenmiştir. Bu haç damgasının içerisinde baklava dilimleri bulunmaktadır. Her bir kolda bir baklava dilimine yer verilir. Baklava dilimlerinin içerisinde daireler bulunmaktadır (Tab. 2). Hayes tarafından Style E (ii) içinde değerlendirilmiştir (Hayes, 1972, s. 279, Type 333). Tarih olarak MS 530-600 arasina tarihlenir (Hayes, 1972, s. 222). Benzerleri: Atina Agorası (Hayes, 1972, s. 279, Fig. 57: 333 e), İber Yarmadasl (Prieto, 1984, s. 529, Fig. 443), Aleksandria Troas (Tüzün 1997, s. 44 Kat. No: 124), Carthage (Mackensen \& Schneider, 2002, s. 148, Fig. 20: 20) ve Parion'da (Ergürer, 2012, s. 408, 414, Kat. No: 249, 261) görülmektedir.

Kat. No. 5; stil D içerisinde değerlendirilmiştir. Genel olarak merkezi bir konumda, bazen yan yana çift veya grup halinde bulunan E (i) Stili'nde de yaygın olarak kullanılır. Haç monogramın içerisinde ince noktalı süsleme kullanılmıştır (Tab. 2). Bazı durumlarda haç'ın kolları altına A ve W eklenir (Hayes, 1972, s. 228). Stil D içerisinde değerlendirilen örnek MS 440-500 arası bir tarihe verilebilir (Hayes, 1972, s. 221). Benzerleri; Atina Agorası'nda (Hayes, 1972, s. 274, Fig. 54: 294 e) görülmektedir.

Tablo 1: Kat. No: 1-2 Afrika Bitkisel ve Hayvan Damga Bezemeli Örnekler.

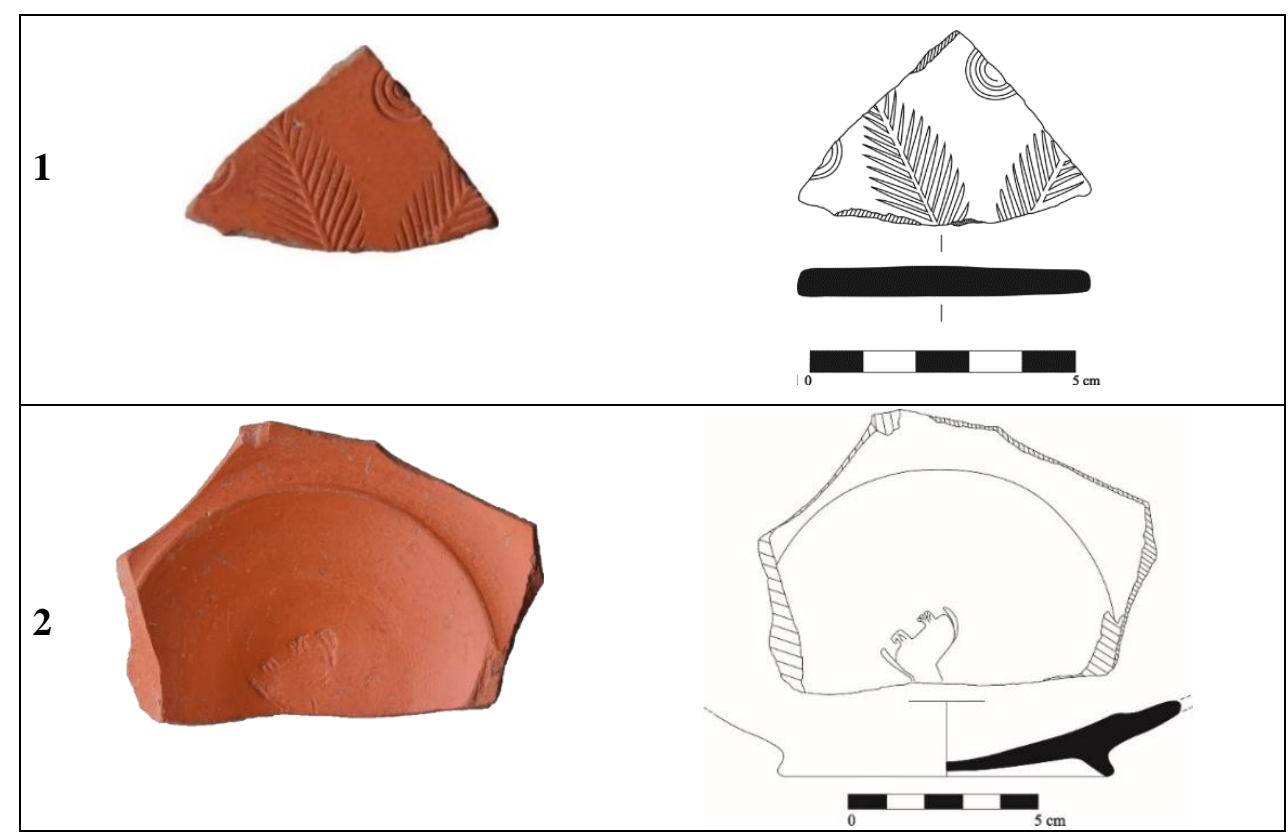


Smintheion Büyük Roma...

DEU Journal of GSSS, Vol: 22, Issue: 4

Tablo 2: Kat. No: 3-5, Afrika İnsan ve Haç Damga Bezemeli Örnekler.

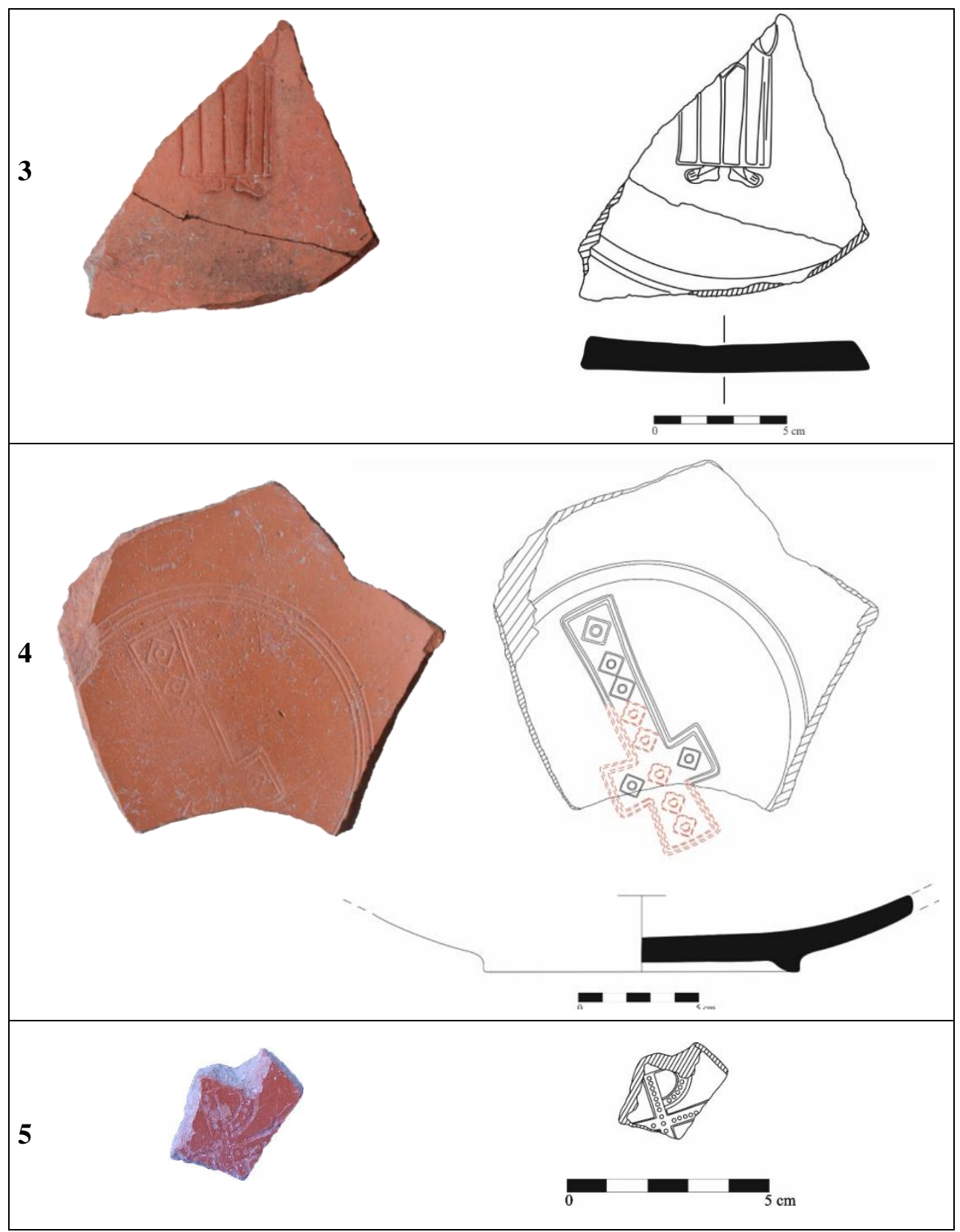




\section{PHOKAİA GEÇ ROMA DAMGA BEZEMELİ SERAMİKLERİ}

Smintheion Büyük Roma Hamamı'nda 2008-2011 yılları arasında gerçekleştirilen kazı çalışmaları sırasında bulunan yirmi dört adet örnek, Phokaia Geç Roma damga bezemeli seramikleri içerisinde değerlendirmeye alınmıştır. 2008 yılında yapılan çalışmalarda ortaya çıkarılan dokuz örneğin iki tanesi bitkisel (Kat. No. 7, 9), üç tanesi hayvan (Kat. No. 14, 16, 20), bir tanesi insan (Kat. No. 21) ve üç tanesi de haç ve varyasyonlarına (Kat. No. 22-24) aittir. 2009 yılında bulunan dört adet örnekten bir tanesi hayvan (Kat. No. 17), üç tanesi de haç/monogram (Kat. No. 25-27) damgası taşımaktadır. 2010 yılındaki çalışmalarda bulunan altı adet örnekten iki tanesi bitkisel (Kat. No. 6, 8), üç tanesi hayvan (Kat. No. 15, 18-19) ve bir tanesin de haç damgası (Kat. No. 28) bulunmaktadır. 2011 yılında ise dört adet geometrik (Kat. No. 10-13) ve bir adet haç damgası (Kat. No. 29) bulunmuştur.

Smintheion Büyük Roma Hamamı'nda yapılan çalışmalarda bulunan dört adet bitkisel damga bezemeden Kat. No. 6; Hayes tarafindan Palm-Branch Style (Hayes, 1972, s. 347) olarak adlandırılan stilize edilmiş Palmiye/hurma yaprakları ile benzerdir. Amorf parça üzerinde merkezde iç içe geçmiş daire etrafında altı adet palmiye yaprağının bezeme dizisini tamamladığı görülmektedir. Bunun dışında palmiye yaprakları yanında iç içe geçmiş beş daire motifi de kullanılmıştır (Tab. 3). Hayes tarafından Grup I içerisinde değerlendirildiği için MS 360-450 arasına (Hayes, 1972, s. 349) tarihlendirilmiştir. Benzerleri; Atina Agorası (Hayes, 1972, s. 350, fig. 72 j: Hayes, 2008, s. 246, Plate 64, Fig. 1337-38), Thasos (Reynal \& Sodini, 1992, s. 25, fig. 8: CF119), Scythia (Opait, 2004, s. 175, Plate 56: 3), Smyrna Agorast (Erol, 2011: s. 439, Kat. No: 356), Parion (Ergürer, 2012, s. 482, Kat. No: 397) ve Antandros'da (Aktaş, 2018, s. 355, Kat. No: 355) görülmektedir.

Kat. No. 7-8'de baskı tekniğiyle yapılmış lotus tomurcuğu motifi yer almaktadır. Lotus tomurcukları lale şeklindedir ve tabanda hafif bir sap vardır. İlk erken örnekleri Grup II A ve B'de (Hayes, 1972, s. 353) görülmektedir. Kat. No. 7 numaralı örnek üzerinde iki lotus tomurcuğu motifi görülebilmektedir. Bu iki motif arasındaki mesafe ve parçanın kaide çapı dikkate alındığında bir tümlemeye gidilerek tabağın kaidesinde sekiz adet lotus tomurcuğunun dairesel motif sırasını oluşturduğu görülmektedir (Tab. 3). Bir diğer lotus tomurcuk Kat. No. 8'e aittir. Örnek üzerinde dairesel üç sıra yiv bandı içerisinde üç adet lotus tomurcuğu bulunmaktadır. Lotus tomurcuklarının kaide üzerindeki konumlarına bakılarak toplamda on adet lotus tomurcuğunun dairesel bezeme sirasinı oluşturduğu görülmektedir (Tab. 4). Hayes tarih olarak da lotus tomurcuğunu Grup II içerisine almış ve MS 440-490 arasında bir tarihi önermiştir (Hayes, 1972, ss. 348-349). Lotus tomurcuklarının benzerleri; Atina Agorası (Hayes, 1972, s. 353, Fig. 73: 1, m ve n: Hayes, 2008, s. 246, Plate 65: fig. 1350,1355), Thasos (Reynal \& Sodini, 1992, s. 26, Fig. 8, Plate I: CF122, CF123), Tarsus (Adibelli, 2006, s. 206, Lev. 27: 308), Smyrna Agorast (Erol, 2011: s. 443, Kat. No:363, s. 526, Kat. No: 563) ve Parion'da (Ergürer, 2012, s. 482, Kat. No: 398) görülmektedir. 
Kat. No. 9'da baskı tekniğiyle yapılmış palmet motifi görülmektedir. Kabın iç kısmında rulet bant sırası altında palmet dizisine ve onun hemen altında da dört yive yer verilmiştir (Tab. 4). Palmet motifleri yiv ve rulet bant içerisinde sınırlandırılmıştır. Elimize geçen parça üzerinde üç palmet motifi görülmektedir. $\mathrm{Bu}$ palmet motiflerinin ikili kümeler halinde hareket ettiği düşünüldügünde kabın kaidesinde toplamda sekiz adet palmet motifi dizisi olmas1 gerekmektedir. MS 5. yüzyılın ilk yarısına tarihlendirilir (Hayes, 1972, ss. 349-351). Benzerleri; Labraunda (Hellström, 1965, s. 74, Plate 16: Fig. 330), Atina Agorası (Hayes, 1972, s. 351, Fig. 73: e, f; Hayes, 2008, s. 239, Plate 60: 1259, s. 243, Plate 63: 1299), Tarsus (Adıbelli, 2006, s. 205, Lev 27: Kat. No: 304), Smyrna Agorast (Erol, 2011, ss. 524-525, Kat. No: 560, 562), Ptolemais (Domzalski, 2012, s. 341, Plate 10: Fig. 2) ve Phokaia'da (Uğuz, 2015, s. 122, Çiz. 9 Kat. No: 39) görülmektedir.

2011 y1lındaki çalışmalar sonucu bulunan dört adet geometrik damga bezemeli örnek çalışılmak üzere değerlendirmeye alınmıştır. Bunlardan Kat. No. 10'un merkezinde konumlandırılmış yalın bir haç motifi, onun hemen üstünde iç içe geçmiş daireler ve en üste eşkenar dörtgen yanlarına eklenmiş dört pelta motif tekrar ederek dairesel bezeme kombinasyonunu tamamlamaktadır (Tab. 5). Parça üzerinde bir tamamlamaya gidildiğinde on iç içe geçmiş daire, on eşkenar dörtgen ve peltalı damganın kullanıldığı görülmektedir. Hayes tarafindan Grup IIB ve III içerisinde değerlendirilir (Hayes, 1972, s. 353). Tarih olarak MS 5. yüzyıl sonu - 6. yüzyıl başına verilir. Benzerleri: Atina Agorası (Waagé, 1933, ss. 299-300, Fig. 4: 226: Hayes, 1972, s. 353, Fig. 73: 17, v,w; Hayes, 2008, s. 246, Plate 60, Fig. 1347), Thasos (Reynal \& Sodini, 1992, s. 26, Plate 1: CF124), Halmyris (Topoleanu, 2003, s. 215, Planche CXIV: 15), Tarsus (Adibelli, 2006, s. 206, Lev. 27: 306), Allianoi (Yeşilova, 2007, s. 195, Kat. No: 192), Smyrna Agorast (Doğer, 2007, s. 112, Plate: VI), Güney Ukrayna (Смокотина, 2009, s.163, pис. 1: 4 a, b), İbida (Mocanu, 2012, s. 109, Fig. 2: 4) ve Antandros'da (Aktaş, 2018, s, 336, 357, Kat. No: 336, 357) görülmektedir.

Kat. No. 11; amorf parçanın üzerinde düzensiz bir şekilde konumlandırılmış dörtgen bezemeler bulunmaktadır. Bezeme, çift yiv içinde baklava şeklinde bir dörtgen ve bunun tam ortasında bir daireden oluşmaktadır. Bunun yanı sıra dörtgenlerin dışında dağınık halde daire motiflerin kullanıldığı görülmektedir (Tab. 5). Bezeme olarak Afrika damgalılarına benzemektedir. MS 5. yüzyılın ortasına tarihlendirilir. Benzerleri; Smyrna Agorası (Erol, 2011, s. 533, Kat. No: 579) ve Antandros'da (Açar, 2017, s. 109, Kat. No: 59) Görülmektedir.

Kat. No. 12 numaralı örnek, amorf olarak bulunan parçada altı sıra yiv üzerinde iki çizgi ile sınırlandırılmış örgü deseni bulunmaktadır (Tab. 6). İnce, uzun ve tek çizgi ile yapılan erken versiyonlarının aksine daha kısa ve bazı noktalarda çift çizgiyle belirtilen örnek grup III içerisinde değerlendirilmiştir (Hayes, 1972, s. 355). MS 470-580 arasında değerlendirilebilir. Benzerleri; Atina Agorası (Hayes, 1972, s. 
355, Fig. 73: 22 dd), Smyrna Agorası (Doğer, 2007, s. 112, Plate: VI: Erol, 2011, s. 448, Kat. No: 374) ve Lübnan'da ( Domzalski, 2013, s. 38, Fig. 14: 6) görülmektedir.

Kat. No. 13 üzerinde iki farklı bezeme unsuru kullanılmıştır. İlk bezeme, birbirini tamamlayan ve tümlenen kaide parçasının merkezinde daire etrafina yerleştirilmiş uç kısımları içe dönük sarmal şeklinde uzanan şekilden oluşmaktadır. Hayes tarafindan Grup III içerisinde değerlendirildiği için tarih olarak ta MS 470580 arasına verilir (Hayes, 1972, s. 349). Bu bezemenin etrafinda dairesel olarak tekrarlanan içerisinde meander ve örgünün yer aldığ dörtgen biçiminde tasarlanmış ikinci bir bezeme bulunmaktadır. Bu dörtgenlerin meander kısımları yukarıya bakarken örgü bezemeler merkezi motife bakacak şekilde tasarlanmıştır (Tab. 6). Daha çok Grup IIB içerisinde görülür (Hayes, 1972, s. 355). MS 440-490 arasına tarihlenir. Merkezde bulunan bezemenin benzerleri; Atina Agorası (Hayes, 1972, s. 357, Fig. 74: 33 i: Hayes, 2008, s. 242, Plate 63, Fig. 1294) ve Smyrna Agorası'nda (Erol, 2011, ss. 531-32, Kat. No: 575-76) görülürken diğer bezemenin benzerleri; Atina Agorası (Waagé, 1933, s. 299, Fig. 4: 227: Hayes, 1972, s. 355, Fig. 74: 26 c, d: Hayes, 2008, s. 246, Plate 65, Fig. 1354), Smyrna Agorast (Erol, 2011, s. 534, Kat. No: 580-81), Phokaia (Uğuz, 2015, s. 172, Çiz. 50: 209) ve Antandros'da (Açar, 2017, s. 100, Kat. No: 48) görülmektedir.

Elimize geçen yedi adet hayvan bezemesinden Kat. No. 14-15' de bask1 tekniği ile yapılmış hareket halinde bir geyik motifine yer verilmiştir (Tab. 7). Geyik Motifleri, Grup II içerisinde değerlendirilen ilk örneklere bakıldığında bunların daha küçük boyutlarda ve şematik yapıldıklarını görüyoruz. Grup III'de ise figürler daha büyük, ayrıntılı ve hareketli işlenmeye başlamıştır (Hayes, 1972, s. 347). Sminthion'daki örneklerin ise Grup III içerisinde değerlendirilmesi doğru olacaktır. Tarih olarak ta Grup III içerisinde değerlendirildikleri için MS 470-580 arasına tarihlendirilmiştir (Hayes, 1972, s. 349). Benzerleri Atina Agorası (Hayes, 1972, s. 359, Fig. 76: 41 a,b), Iber Yartmadast (Prieto, 1984, s. 550, Fig. 6), Halmyris (Topoleanu, 2003, Planche CXIV: 19), Chersonesos (Zuhuravlev, 2002, s. 267, Fig. 21: 37), Smyrna Agorass (Erol, 2011, s. 463, Kat. No: 405) ve Parion'da (Ergürer, 2012, s. 486 Kat. No: 405) görülmektedir. Ayrıca Hayes bu örneğin stilistik açıdan benzerinin Apollonia, Cyrenaica ve Byzantine Palace'da olduğunu da söylemektedir (Hayes, 1972, s. 359, Fig. 76: b).

Hayvan damga bezemeli bir diğer örneğimiz tavşan bezemesinden oluşmaktadır. Toplamda üç adet örnek değerlendirmeye alınmış olup bunlardan Kat. No. 16'da, kaidenin iç yüzeyinde tekrar eden yivler ve bu yivlerin hemen altında baskı tekniğiyle yapılmış tavşan figürü yer almaktadır (Tab. 7). Figür, genellikle daha basit ve stilize edilenlerin aksine daha gerçekçi işlenmiştir. Grup II ve III içerisinde örnekleri bulunan tavşan motiflerinin ilk örneklerinin stilize işlendiği, zamanla figürlerin tasvirlerinde detaylara yer verilmeye başlandığı görülmektedir. Genellikle tavşan, köpek ve tazı benzeri olarak tasarlanabilirler. Tarih olarak da figürün detayları ve boyutu dikkate alındığında MS 6. yüzyılın ilk yarısına 
tarihlendirilir (Hayes, 1972, s. 347, 357). Benzerleri; Demetrias (Eiwanger, 1981, Tafel 7: II. 85), Atina Agorasl (Hayes, 2008, s. 239, Plate 60: 1261, s. 247, Plate 66: 1362), Tarsus (Adıbelli, 2006, Lev. 28: 314-316), Parion (Ergürer, 2016, s. 141 Fig. 6: 110; Ergül, 2019, Res. 9: 48) ve Antandros'da (Aktaş, 2018, s. 341, Kat. No: 341) bulunmuştur.

Kat. No. 17'de kaide parçasında rulet bezeme sırası arasında koşar durumda iki tavşan/tazı damgası bulunmaktadır. Figürler basit işlenerek stilize edilmiştir. İki figürde her iki ayakları arkada gösterilerek koşar vaziyettedir. Soldaki figür başını hemen arkasından gelen diğer figüre çevirmiştir. Sağdaki figür açık bir ağıza sahiptir ve kıvrımlı bir kuyruk yapısı vardır (Tab. 8). MS 440-490 arasına tarihlendirilir (Hayes, 1972, ss. 347-349). Benzerleri: Antiocheia (Waagé, 1948, fig. 33), Atina Agorast (Hayes, 1972, s. 357, Fig. 74: 35 1, Fig. 75: 35 b: Hayes, 2008, s. 240, Plate 61: 1267, s. 247, Plate 67: 1380), Iber Yarımadast (Prieto, 1984, s. 550, Fig. 19.2: 5, s. 551, Fig. 19. 3: 2), Tarsus (Adibelli, 2006, s. 208, Lev. 28: Kat. No: 314) ve Parion'da (Ergürer, 2012, s. 484, Kat. No: 402) görülmektedir.

Kat. No. 18'de kaide parçasında bir tavşan damgası bulunmaktadır (Tab. 8). Figürün baş kısmı döndürülmüş olup her iki ayağı arkada gösterilerek koşar vaziyettedir. Benzerleri; Atina Agorasl (Hayes, 1972, s. 357, fig. 74: 35 t) ve Tarsus'da (Adıbelli, 2006, s. 208, Lev. 28: Kat. No: 316) görülmektedir. Grup II içerisinde değerlendirildiği için MS 440-490 arasına tarihlendirilir (Hayes, 1972, ss. 347-349).

Kat. No. 19 numaralı örnek; amorf parça üzerinde bir kuş damgası bulunmaktadır. Bezemenin gövde, kanat ve boyun kısmında çizgiler dekorasyonu tamamlar nitelikte olup detayların arttığı görülmektedir. Bacaklar açıktır (Tab. 8). Her ne kadar parça üzerinde kuyruk görülmese de vucüt hatlarının işlenme şekli kuşun uzun bir kuyruğa sahip olabileceğini göstermektedir. Hayes tarafından Grup III (erken) içerisinde değerlendirildiği için MS 6. yüzyıl ortasına tarihlenebilir (Hayes, 1972, s. 362). Benzerleri: Antiocheia (Waagé, 1948, ss. 53-54, fig. 33), Atina Agorası (Hayes, 1972, s. 362, Fig. 77: 50 h), Smyrna (Erol, 2011, s. 168, Kat. No: 400) ve Parion'da (Ertuğ 2012, s. 485, Kat. No: 403) görülmektedir.

Kat. No. 20'de amorf parçanın merkezinde baskı tekniğiyle yapılmış muhtemelen at olabilecek bir hayvan tasviri yer almaktadır (Tab. 9). Figürün sadece arka ayakları ve gövdesi görülebilmektedir. Grup II içerisinde değerlendirilen örnek MS 440-490 arasina tarihlendirilir (Hayes, 1972, s. 349). Benzeri Chersonesos'da (Zuhuravlev, 2002, s. 267, Fig. 21: 39) görülmektedir.

Kat. No. 21; Phokaia damga bezemelileri içerisinde ele geçen tek insan betimlemeli örnektir. Hareketli bir insan figürü ile yanında bir kuş motifine yer verilmiştir (Tab. 9). Bu tip insan betimlemeleri sınırlı sayıdadır. Figürler çoğunlukla çok kaba özellikle yüz, el ve ayak tasvirleri kabaca işlenmiştir (Hayes, 1972, s. 348, 362). Parçanın merkezinde baskı tekniğiyle yapılmış, tunik giymiş figür elini 
kaldırarak İmparatoru selamlıyor olmalıdır. Figürde kılıcında betimlenmesi venator olma ihtimalini de yükseltmektedir. Figürün bacakları profilden verilirken geri kalan kısmı cepheden verilmiştir. Örnek MS 6. yüzyıl içerisinde değerlendirilir (Hayes, 1972, ss. 348-349). Benzerleri; Atina Agorast (Hayes, 1972, s. 362, Fig. 77: 56 m; Hayes, 2008: s. 248, Plate 68: 1395-96) ve Smyrna'da (Erol, 2011, s. 170, Kat. No: 411) görülmektedir.

2008-2011 yılları arasında yapılan çalışmalar sonucu bulunan haç ve monogramlardan sekiz tanesi çalışılmak üzere değerlendirmeye alınmıştır. Kat. No. 22'de parçanın merkezinde baskı tekniğiyle yapılmış dörtgen üzerinde haç işaretine yer verilmiştir (Tab. 9). Grup II A-B içerisinde değerlendirilebilir ve tek başına merkezde ya da diğer motiflerle ortak olarak kullanılabilmektedir (Hayes, 1972, s. 357). Grup II içerisinde değerlendirildiği için MS 440-490 arasına tarihlendirilmiştir (Hayes, 1972, ss. 348-349). Benzerleri; Antiocheia (Waage, 1948, ss. 53-54 Fig. 34), Atina Agorası (Hayes, 1972, s. 357, Fig. 74: j; Hayes, 2008: s. 246, Plate 65: 1347), Phokaia (Uğuz, 2015, s. 172, Çiz. 49, Kat. No: 208) ve Parion'da (Ergül, 2019, s. 56, Res. 9: K-47) görülmektedir.

Kat. No. 23'de kabın merkezinde bulunan baskı tekniğiyle yapılmış haç motifi bulunmaktadır (Tab. 10). Grup III'ün bir özelliği olan merkezinde genellikle tek bir damga ( en yaygın olanı haç ve haç monogramları) bulunur (Hayes, 1972, s. 348). Parçanın merkezinde bulunan haç motifi kolları altında konsantrik dairelerden birisi gözükmektedir. Parça kırık olduğu için diğer konsantrik daire gözükmemektedir. Grup III içersinde değerlendirildiği için MS 6. yüzyıl başına tarihlendirilir (Hayes, 1972, s. 365, Fig. 78: 68). Benzerleri: Antiocheia (Waagé, 1948, ss. 53-54, Fig. 34), Atina Agorast (Hayes, 1972, s. 365, Fig. 78: 68 j, k), Thasos (Reynal \& Sodini, 1992, s. 27, Plate: CF136), Chhim (Domzalski, 2002, s. 82, Fig. 70), Ephesos (Ladstatter \& Sauer, 2005, s. 188, Taf. 2: 25, s. 194, Taf. 8: 106), Tarsus (Adıbelli, 2006, s. 209, Lev. 28: 321), Troia (Heath \& Tekkök, 2007 - 2008, s. 75: 26), Smyrna Agorası (Doğer, 2007, s. 111, Plate V: d, h; Erol, 2011, Kat. No: 389, 599, 601), , Ashkelon (Johnson, 2008, s. 72: 219-220), Güney Ukrayna (Смокотина , 2009, ss. 170-171, pис. 8: 40 b1, pис. 9: 41, a-b, 45a), Parion (Ergürer, 2012: s. 489, Kat. No: 412), İbida (Mocanu, 2012, s. 110, Fig. 3: 13), Assos (Ayaz, 2014, s. 125, Lev. 55: Kat. No: 220-221), Myndos (Asar Adasi) (Mimaroğlu, 2017, s. 345, Fig. 4) ve Antandros 'da (Açar, 2017, s. 104, Kat. No: 57) görülmektedir.

Kat. No. 24'de parçanın merkezinde baskı tekniğiyle yapılmış haç motifine yer verilmiştir. Çift dış çizgili bir haç damgası vardır (Tab. 10). Normalde düz kare uçlu kollarla, birkaç varyantın kolları vardır. MS 5. yüzyıl sonundan 6. yüzyıl başına tarihlendirilir (Hayes, 1972, s. 365). Benzerleri: Atina Agorası (Hayes, 1972, s. 365 , Fig. 79: 71 c: Hayes, 2008, s. 246, Plate 68: 1404), Sardes (Rautman, 1995, s. 44, Fig. 4: 1.10), Smyrna Agorası (Doğer, 2007: s. 111, PI. V: g) ve İzmir Karaburun'da (Yukarı Boyabağ) (Aktaş vd., 2019, s. 410, Fig. 5: b) görülmektedir. 
Kat. No. 25'de kaide parçasının iç kısmında merkezi motif olarak bir haç damgası kullanılmıştır. Haç'ın kolları arasında dört adet daire bulunmaktadır. Haç'ın her bir kolu düz uzanıp uçları dışa doğru genişlemektedir (Tab. 10). Grup III içerisinde değerlendirilen örnek, MS 470-580 arası bir tarihe verilir (Hayes, 1972, s. 349). Benzerleri; Atina Agorası (Hayes, 1972, s. 368, Fig. 79: 79 r: Hayes, 2008, s. 248, Plate 69, Fig. 1408), Thasos (Reynal \& Sodini, 1992, s. 28, Fig. 10: CF142) ve Tarsus'da (Adıbelli, 2006, s. 209, Lev. 28: Kat. No: 320) görülmektedir.

Kat. No. 26' da amorf olarak ele geçen parça üzerinde çift yivli/çizgili bir haç monogramı bulunmaktadır (Tab. 11). Haç'ın dikey çizgileri sürekli olup kesilmeden devam eder. Uç kısımları yayvan dışa doğru dönüktür. Sol ve sağ kolların altında alfa ve omega işareti bulunmaktadır. Hayes tarafından MS 5. yüzyılın sonlarına tarihlendirilir (Hayes, 1972, s. 363). Benzerleri; Atina Agorası (Hayes, 1972, s. 363, Fig. 78: 65 g: Hayes, 2008, s. 248, Plate 69: 1414), Smyrna Agorası (Doğer, 2007, s. 111, Plate V: i) ve Assos'da (Ayaz, 2014, s. 126, Lev. 55: 223) görülmektedir.

Kat. No. 27'de iki kol altında Alfa ve Omega işareti bulunan haç monogramına aittir (Tab. 11). Uzantılar hafif çizgiler ile verilmiştir. Tarih olarak Grup III içerisinde değerlendirildiği için MS 470-580 (Hayes, 1972, ss. 348-349) arasina verilir. Benzerleri; Atina Agorast (J. W. Hayes, 1972, s. 363, Fig. 78: 66 h: Hayes, 2008, s. 248, Plate 69: 1416), Thasos (Reynal \& Sodini, 1992, s. 27, Fig. 9: CF132), Halmyrs (Topoleanu, 2003, s. 216, Planche CXV: 24), Tarsus (Adibelli, 2006, s. 210, Lev. 28: 324), Smyrna Agorasi (Doğer, 2007, s. 111, Plate V: i), Ibida (Mocanu, 2012, s. 110, Fig. 3: 14) ve Lübnan'da (Domzalski, 2013, s. 40, Fig. 16: 1) bulunmaktadır.

Kat. No. 28; kaidenin merkezine konumlandırılmış çift kontürlü bir haç motifi bulunmaktadır (Tab. 11). Kollar az da olsa dışa doğru genişler durumdadır. Büyük oranda korunmuş örnek üzerinde haç'ın üç kolu gözükmektedir. Dikey kol üzerinde sonradan açılmış olabilecek iki delik izi görülmektedir. Grup III içerisinde değerlendirilen örnek, MS 470-580 arasına tarihlendirilmektedir (Hayes, 1972, s. 365). Benzerleri; Antiocheia (Waagé, 1948, ss. 53-54, Fig. 34), Atina Agorast (Hayes, 1972, s. 365, Fig. 79: 71 c, d: Hayes, 2008, s. 248, Plate 68: 1404), Thasos (Reynal \& Sodini, 1992, s. 28, Fig. 10: CF141), Halmyris (Topoleanu, 2003, s. 216, Planche CXV:22), Ephesos (Ladstätter \& Sauer, 2005, s. 178, Taf. 8: 109-110), Smyrna Agorası (Doğer, 2007, s. 111, Plate V: g), Tarsus (Adıbelli, 2006, s. 211, Lev. 29: 330), Lübnan (Domzalski, 2013, s. 40, Fig. 16: 7) ve Parion'da (Ergül, 2019, s. 57, Res. 10: K-52) görülmektedir.

Kat. No. 29'da Amorf parçanın merkezinde çift yivli bir Yunan haç'1 bulunmaktadır (Tab. 12). Haç'ın dikey kolu yan kolları keser şekilde yapılmıştır. MS 5. yüzyıl ortasına tarihlenir. Benzerleri; Atina Agorası (J. W. Hayes, 1972, s. 365, Fig. 78: 69 o: Hayes, 2008, s. 248, Plate 68: 1403), Parion, (Başaran \& Ergürer, 
2012, s. 272, Fig. 9, Kat. No: 25) ve Antandros'da (Aktaş, 2018, s. 356, Kat. No: 356) görülmektedir.

Tablo 3: Kat. No: 6-7, Phokaia Bitkisel Damga Bezemeli Örnekler.

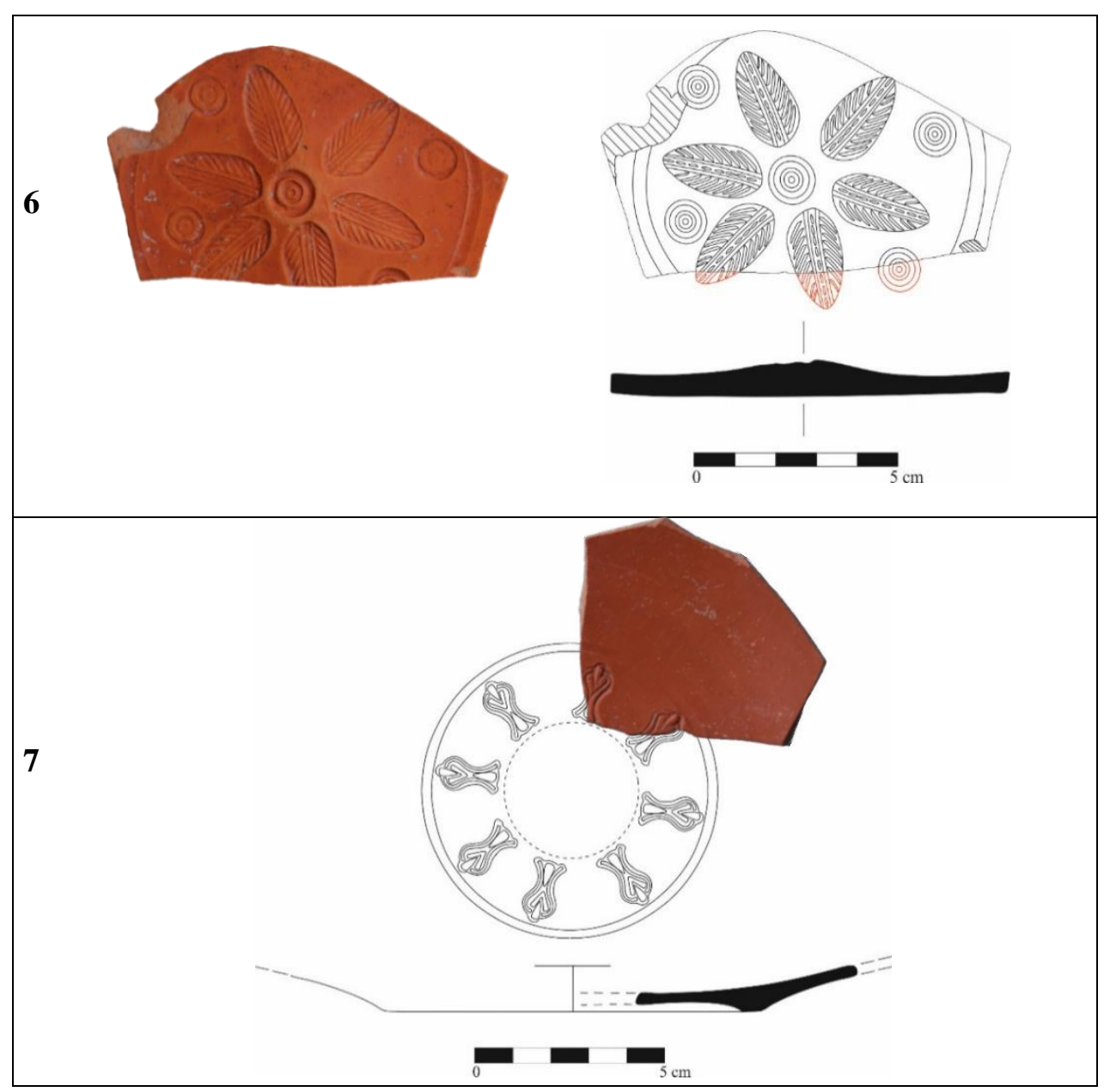


Smintheion Büyük Roma...

DEU Journal of GSSS, Vol: 22, Issue: 4

Tablo 4: Kat. No: 8-9, Phokaia Bitkisel Damga Bezemeli Örnekler.

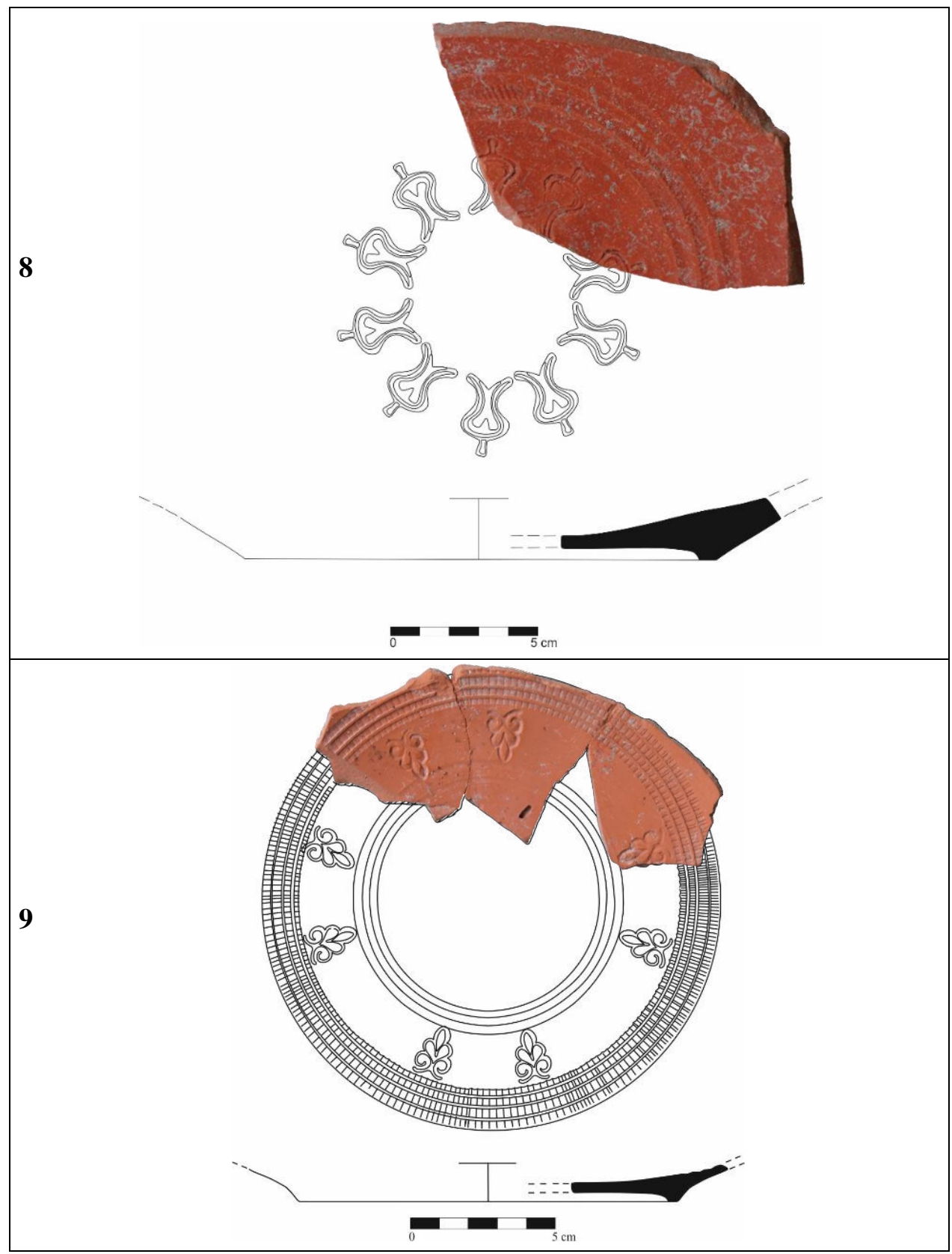


Tablo 5: Kat. No: 10-11, Phokaia Geometrik Damga Bezemeli Örnekler.

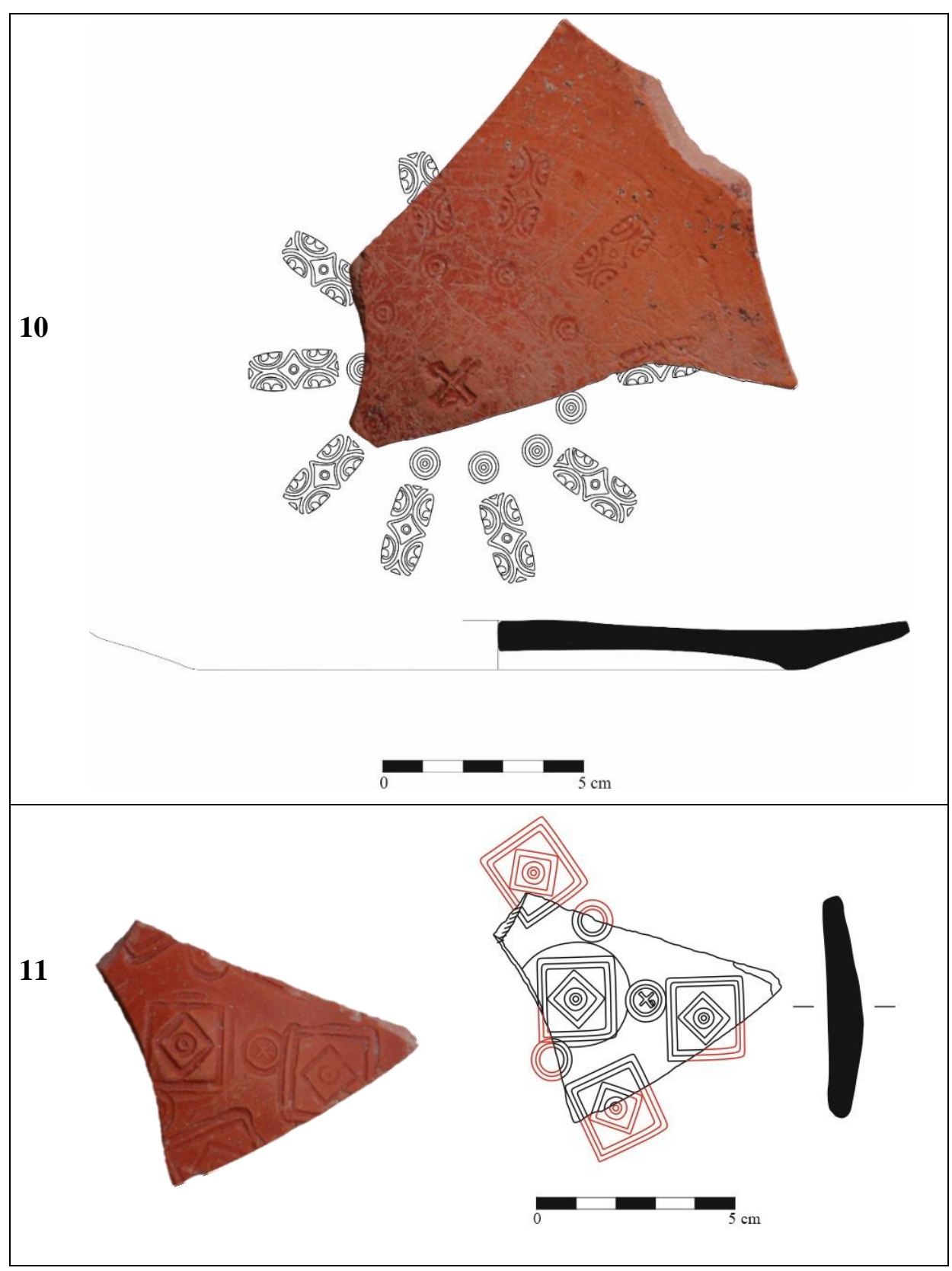


Smintheion Büyük Roma ...

DEU Journal of GSSS, Vol: 22, Issue: 4

Tablo 6: Kat. No: 12-13, Phokaia Geometrik Damga Bezemeli Örnekler.

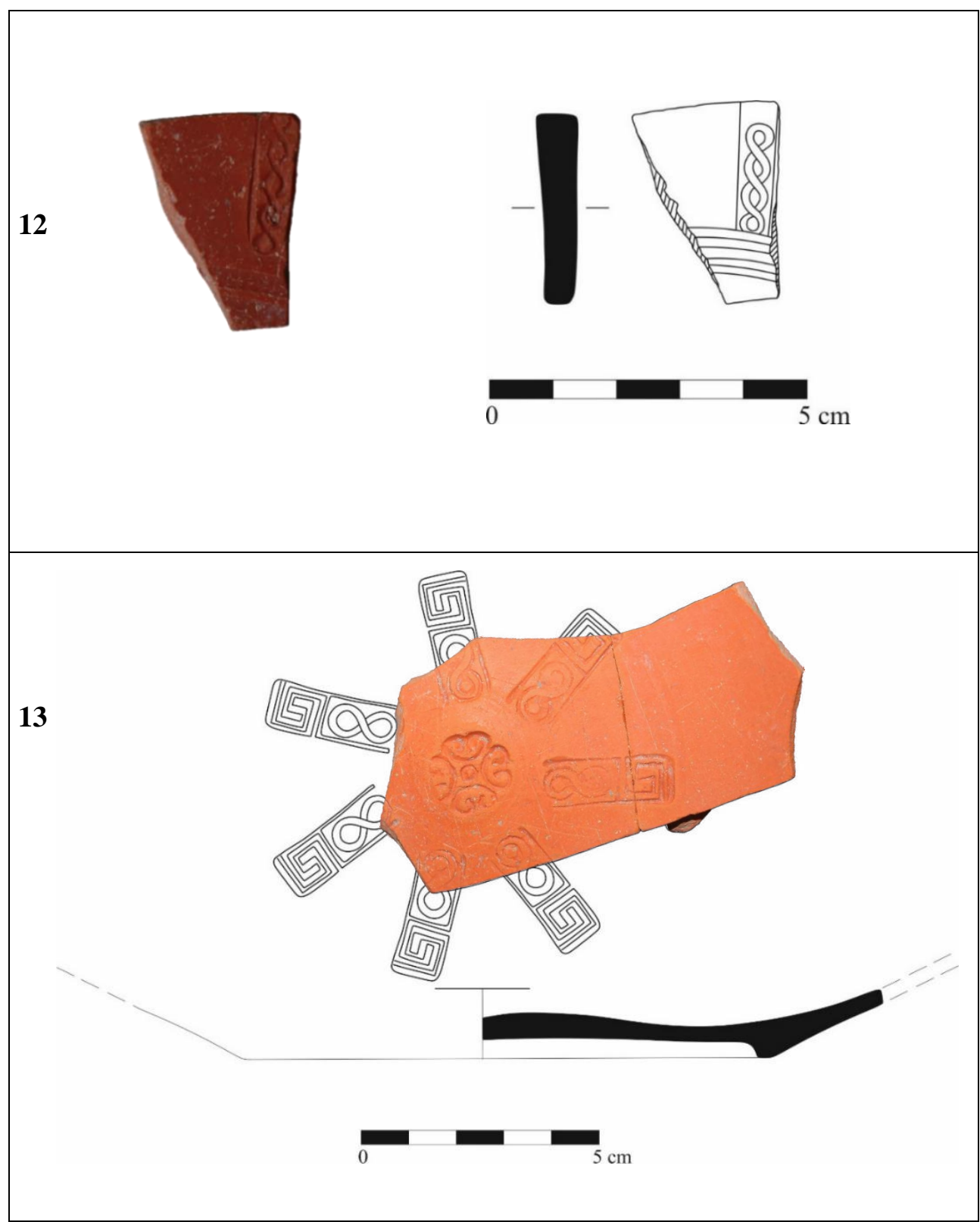


Tablo 7: Kat. No: 14-16, Phokaia Hayvan Damga Bezemeli Örnekler.

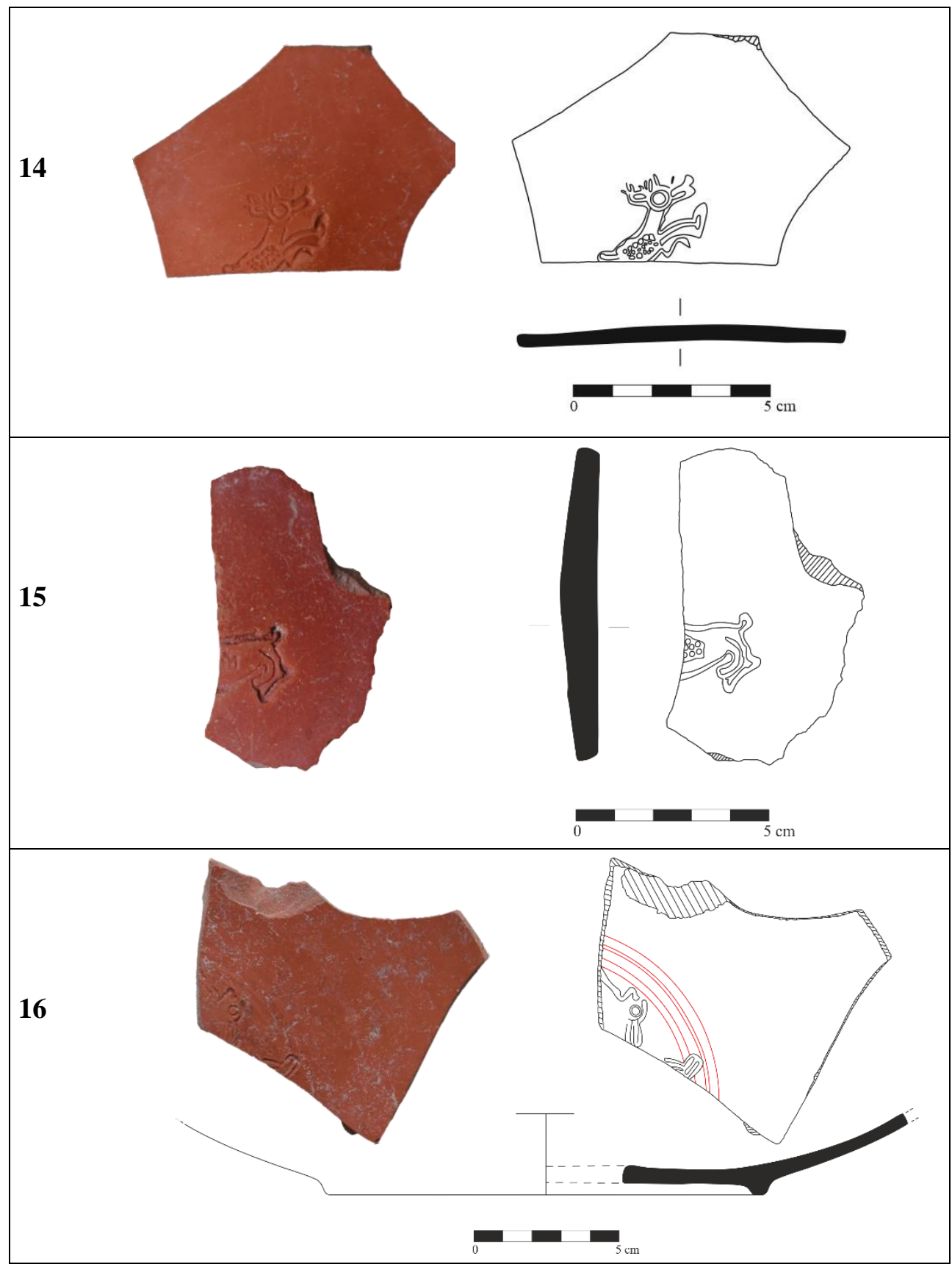


Smintheion Büyük Roma...

DEU Journal of GSSS, Vol: 22, Issue: 4

Tablo 8: Kat. No: 17-19, Phokaia Hayvan Damga Bezemeli Örnekler.

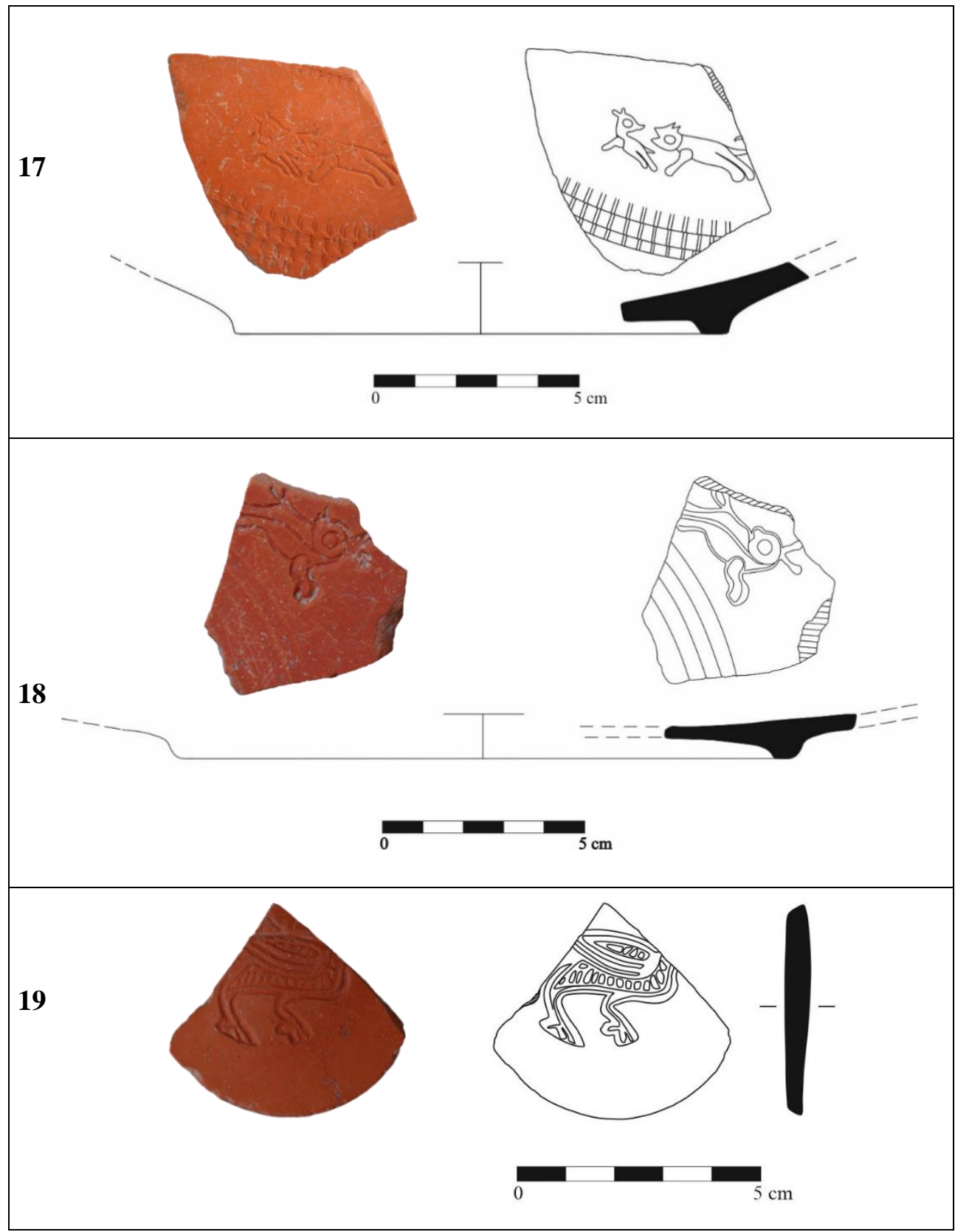


Tablo 9: Kat. No: 20-22, Phokaia Hayvan, İnsan ve Haç Damgalı Örnekler.

20


Smintheion Büyük Roma ...

DEU Journal of GSSS, Vol: 22, Issue: 4

Tablo 10: Kat. No: 23-25, Phokaia Haç Damga Bezemeli Örnekler.

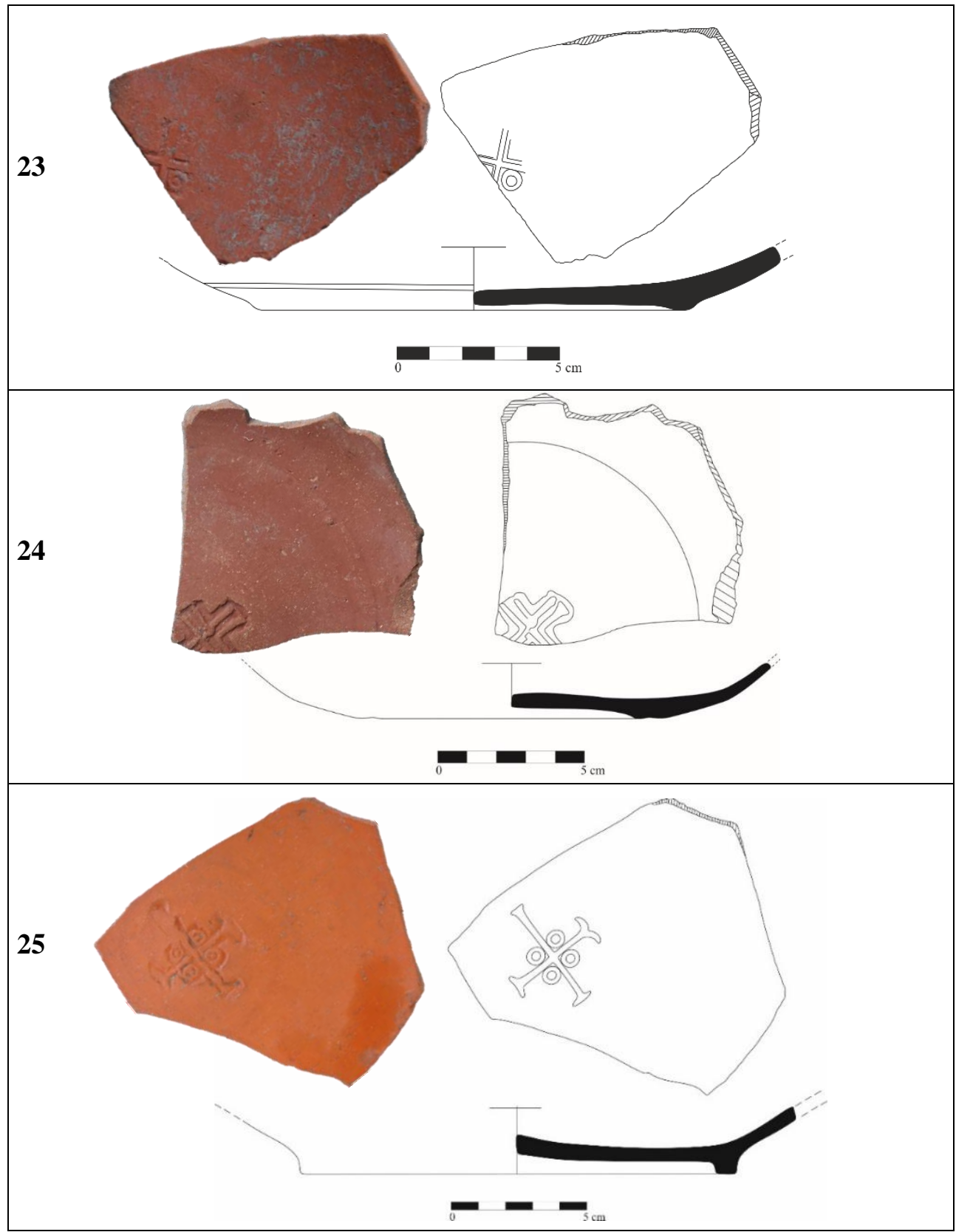


Tablo 11: Kat. No: 26-28, Phokaia Haç Damga Bezemeli Örnekler.

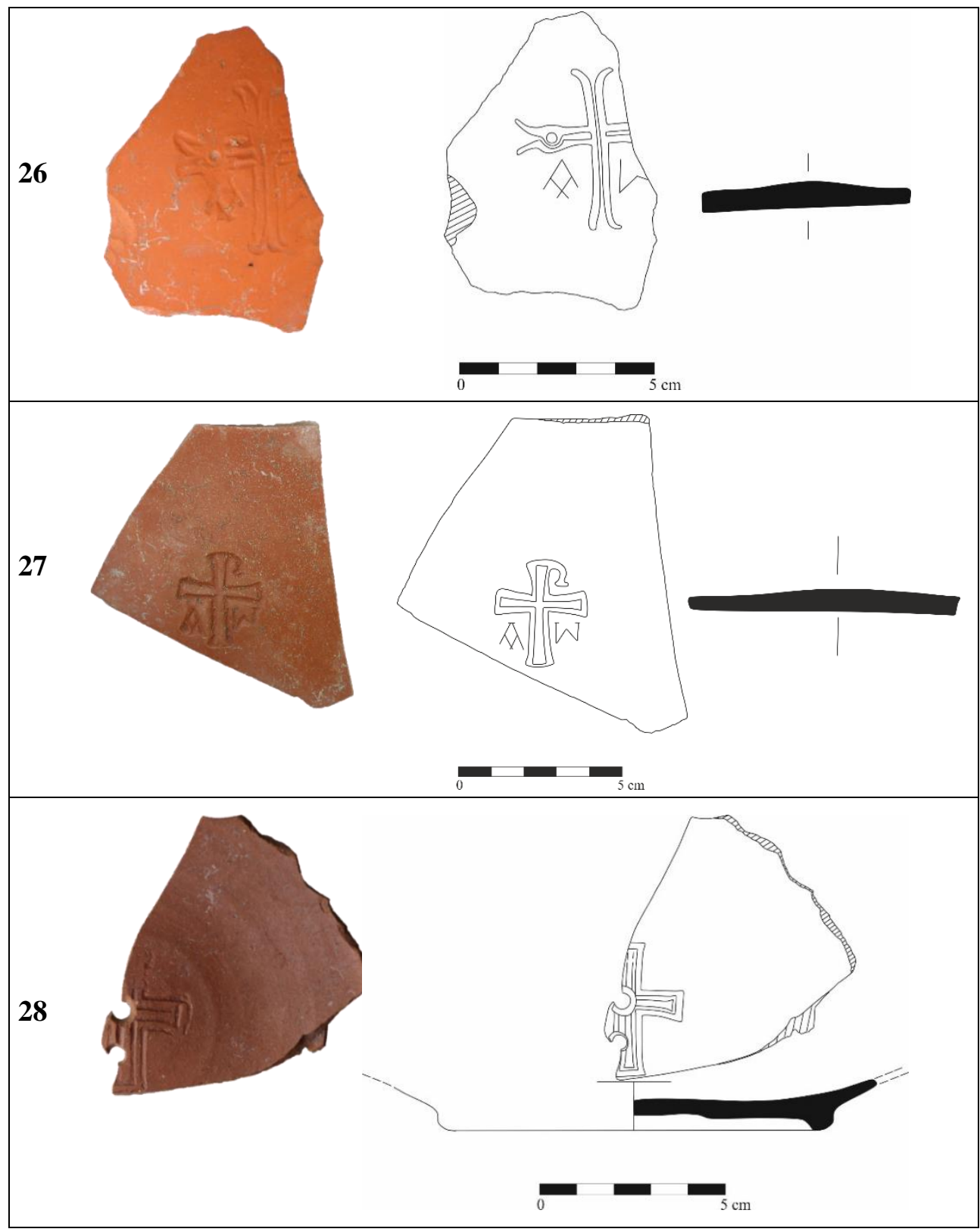


Tablo 12: Kat. No: 29 Phokaia Haç Damga Bezemeli Örnek.

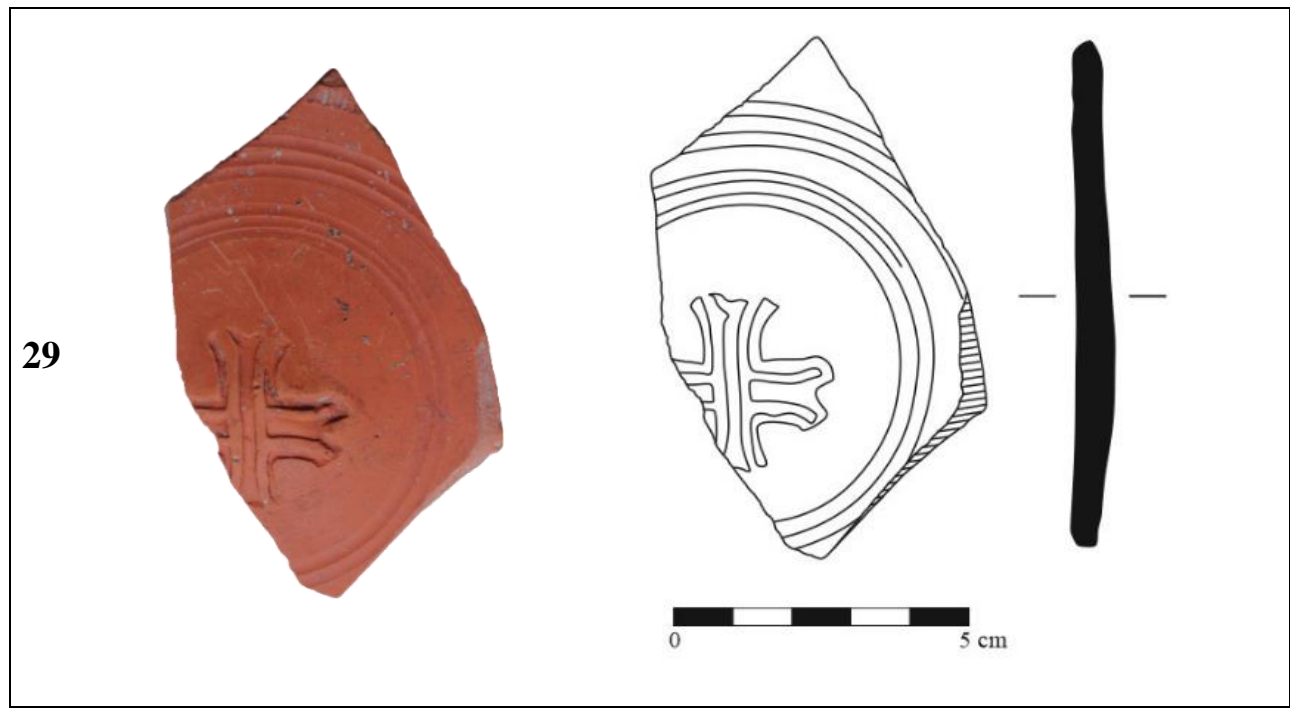

\section{KATALOG}

Kat. No: 1

Res./Levha: Tablo 1

Genişlik: $5.5 \mathrm{~cm}$

Hamur Rengi: 10 R 6/8

Astar Rengi: 2.5 YR 6/8

Tarih: MS 4-5 yüzyıl

Ref.: Hayes, 1972, s. 229, Fig. 38: c.

Kat. No: 2

Res./Levha: Tablo 1

Yükseklik: $2 \mathrm{~cm}$

Dip Çapı: $8.6 \mathrm{~cm} 5.5 \mathrm{~cm}$

Hamur Rengi: 5 YR 6/8

Astar Rengi: 2.5 YR 6/8

Tarih: MS 480-540

Ref.: Hayes, 1972, s. 256, Fig. 48: 166-

169.

Kat. No: 3

Res./Levha: Tablo 2

Genişlik: $11 \mathrm{~cm}$

Hamur Rengi: 5 YR 6/6

Astar Rengi: 2.5 YR 6/8

Tarih: MS 6. yüzyılın ikinci yarıs1

Ref.: Hayes, 1972, s. 266, Fig 51: 235 e.

Kat. No: 4

Res./Levha: Tablo 2 
Yavuz, $O$.

Yükseklik: $3.2 \mathrm{~cm}$

Hamur Rengi: 5 YR 7/8

Tarih: MS 530-600

Kat. No: 5

Genişlik: $3 \mathrm{~cm}$

Hamur Rengi: 5 YR 7/8

Tarih: MS 440-500

Kat. No: 6

Genişlik: $10 \mathrm{~cm}$

Hamur Rengi: 5 YR 7/8

Tarih: MS 360-450

Kat. No: 7

Yükseklik: $1.2 \mathrm{~cm}$

Hamur Rengi: 5 YR 6/6

Tarih: MS 440-490

Kat. No: 8

Yükseklik: $2 \mathrm{~cm}$

Hamur Rengi: 2.5 YR 6/6

Tarih: MS 440-490
DEÜ SBE Dergisi, Cilt: 22, Sayl: 4

Dip Çapı: $8.6 \mathrm{~cm} 13 \mathrm{~cm}$

Astar Rengi: 5 YR 6/8 / 2.5 YR 6/8

Ref. : Hayes, 1972, s. 279, Fig. 57: 333 e.

Res./Levha: Tablo 2

Astar Rengi: 10 R 5/8

Ref. : Hayes, 1972, s. 274, Fig. 54: 294 e.

Res./Levha: Tablo 3

Astar Rengi: $\quad 2.5$ YR 6/8

Ref. : Hayes, 1972, s. 350, fig. 72 j.

Res./Levha: Tablo 3

Taban Çapı: $10 \mathrm{~cm}$

Astar Rengi: 2.5 YR 5/6

Ref. : Hayes, 1972, s. 353, Fig. 73: 1, m.

Res./Levha: Tablo 4

Taban Çapı: $16 \mathrm{~cm}$

Astar Rengi: 2.5 YR 5/8 / 10 R 5/8

Ref. : Hayes, 1972, s. 353, Fig. 73: n. 
Smintheion Büyük Roma...

Kat. No: 9

Yükseklik: $1.2 \mathrm{~cm}$

Hamur Rengi: 5 YR 7/8

Tarih: MS 5. yüzyılın ilk yarısı

Kat. No: 10

Yükseklik: $1.2 \mathrm{~cm}$

Hamur Rengi: 5 YR 7/6

Tarih: MS 5. yy. sonu - 6. yy. baş1

Kat. No: 11

Genişlik: $7.3 \mathrm{~cm}$

Hamur Rengi: 5 YR 7/8

Tarih: MS 5. yüzyılın ortas1

Kat. No: 12

Genişlil: $2.4 \mathrm{~cm}$

Hamur Rengi: 5 YR 6/6

Tarih: MS 470-580

Kat. No: 13

Yükseklik: $1.4 \mathrm{~cm}$

Hamur Rengi: 5 YR 7/8

Tarih: MS 440-490

Kat. No: 14

Genişlil: $8.3 \mathrm{~cm}$

Hamur Rengi: 10 R 6/6

Tarih: MS 470-580
DEU Journal of GSSS, Vol: 22, Issue: 4

Res./Levha: Tablo 4

Taban Çapı: $13 \mathrm{~cm}$

Astar Rengi: 2.5 YR 6/8

Ref. : Hayes, 1972, s. 351, Fig. 73: e, f.

Res./Levha: Tablo 5

Taban Çapı: $15 \mathrm{~cm}$

Astar Rengi: 10 R 5/8

Ref. : Hayes, 1972, s. 353, Fig. 73: 17, v,w.

Res./Levha: Tablo 5

Astar Rengi: 2.5 YR 6/8

Ref. : Erol, 2011, s. 533, Kat. No: 579.

Res./Levha: Tablo 6

Astar Rengi: 2.5 YR 6/8

Ref. : Hayes, 1972, s. 355, Fig. 73: 22 dd.

Res./Levha: Tablo 6

Taban Çapı: $12 \mathrm{~cm}$

Astar Rengi: 2.5 YR 6/8

Ref. : Hayes, 1972, s. 357, Fig. 74: 33 i.

Res./Levha: Tablo 7

Astar Rengi: 10 R 5/8

Ref. : Hayes, 1972, s. 359, Fig. 76: 41 a, b. 
Kat. No: 15

Res./Levha: Tablo 7

Genişlik: $4.9 \mathrm{~cm}$

Hamur Rengi: 2. 5 YR 6/6

Tarih: MS 470-580

Kat. No: 16

Yükseklik: $2.8 \mathrm{~cm}$

Hamur Rengi: 2.5 YR 6/6

Tarih: MS 6. yüzyılın ilk yarısı

Kat. No: 17

Yükseklik: $1.7 \mathrm{~cm}$

Hamur Rengi: 5 YR 7/6

Tarih: MS 440-490

Kat. No: 18

Yükseklik: $1 \mathrm{~cm}$

Hamur Rengi: 5 YR 7/8

Tarih: MS 440-490

Kat. No: 19

Genişlik: $4.8 \mathrm{~cm}$

Hamur Rengi: 5 YR 7/8

Tarih: MS 6. yüzyılın ilk yarıs1

Kat. No: 20

Yükseklik: $1.5 \mathrm{~cm}$

Hamur Rengi: 5 YR 7/4

Tarih: MS 440-490
Astar Rengi: 10 R 5/6, 5/8

Ref. : Hayes, 1972, s. 359, Fig. 76: 41 a,b.

Res./Levha: Tablo 7

Taban Çapı: $15 \mathrm{~cm}$

Astar Rengi: 10 R 5/8

Ref. : Hayes, 2008, s. 239, 247, Plate 60, 66: $1261,1362$.

Res./Levha: Tablo 8

Taban Çapı: $12 \mathrm{~cm}$

Astar Rengi: 2.5 YR 6/8

Ref. : Hayes, 1972, s. 357, Fig. 74: 35 1, Fig. $75: 35 \mathrm{~b}$.

Res./Levha: Tablo 8

Taban Çapı: $15 \mathrm{~cm}$

Astar Rengi: 2.5 YR 6/8

Ref. : Hayes, 1972, s. 357, fig. 74: 35 t.

Res./Levha: Tablo 8

Astar Rengi: 2.5 YR 6/8

Ref. : Hayes, 1972, s. 362, Fig. 77: 50 h.

Res./Levha: Tablo 9

Taban Çapı: $10 \mathrm{~cm}$

Astar Rengi: 2.5 YR 5/6

Ref. : Zuhuravlev, 2002, s. 267, Fig. 21: 39. 1338 
Kat. No: 21

Genişlik: $7.5 \mathrm{~cm}$

Hamur Rengi: 5 YR 7/6

Tarih: MS 6. yüzyıl ortası

Kat. No: 22

Genişlik: $7.4 \mathrm{~cm}$

Hamur Rengi: 2.5 YR 6/6

Tarih: MS 440-490

Kat. No: 23

Yükseklik: $1.9 \mathrm{~cm}$

Hamur Rengi: 5 YR 7/6

Tarih: MS 6. yüzyıl başı

Kat. No: 24

Yükseklik: $1.9 \mathrm{~cm}$

Hamur Rengi: 5 YR 8/4

Tarih: MS 5. yy. sonu 6. yy. baş1

Kat. No: 25

Yükseklik: $2.5 \mathrm{~cm}$

Hamur Rengi: 2.5 YR 6/6

Tarih: MS 470-580

Kat. No: 26

Genişlik: $5 \mathrm{~cm}$

Hamur Rengi: 2.5 YR 6/8

Tarih: MS 5. yüzyıl sonları
Res./Levha: Tablo 9

Astar Rengi: 10 R 6/8

Ref. : Hayes, 1972, s. 362, Fig. 77: 56 m.

Res./Levha: Tablo 9

Astar Rengi: 2.5 YR 5/8

Ref. : Hayes, 1972, s. 357, Fig. 74: j.

Res./Levha: Tablo 10

Taban Çapı: $13 \mathrm{~cm}$

Astar Rengi: 10 R 6/8

Ref. : Hayes, 1972, s. 365, Fig. 78: 68 j, k.

Res./Levha: Tablo 10

Taban Çapı: $10 \mathrm{~cm}$

Astar Rengi: 10 R 6/6

Ref. : Hayes, 1972, s. 365, Fig. 79: 71 c.

Res./Levha: Tablo 10

Taban Çapı: $16 \mathrm{~cm}$

Astar Rengi: 2.5 YR 6/8

Ref. : Hayes, 1972, s. 368, Fig. 79: 79 r.

Res./Levha: Tablo 11

Astar Rengi: 2.5 YR 6/8

Ref. : Hayes, 1972, s. 363, Fig. 78: 65 g. 
Kat. No: 27

Res./Levha: Tablo 11

Genişlik: $8.3 \mathrm{~cm}$

Hamur Rengi: 5 YR 7/6

Astar Rengi: 2.5 YR 6/8

Tarih: MS 470-580

Ref. : J. W. Hayes, 1972, s. 363, Fig. 78: 66

h.

Kat. No: 28

Yükseklik: $1.3 \mathrm{~cm}$

Hamur Rengi: 5 YR 5/6

Tarih: MS 470-580

Kat. No: 29

Genişlik: $5.5 \mathrm{~cm}$

Hamur Rengi: 5 YR 7/8

Tarih: MS 5. yüzyıl ortas1
Res./Levha: Tablo 11

Taban Çapı: $10 \mathrm{~cm}$

Astar Rengi: 5 YR 5/6

Ref. : Hayes, 1972, s. 365, Fig. 79: 71 c, d.

Res./Levha: Tablo 12

Astar Rengi: 2. 5 YR 6/8

Ref.: J. W. Hayes, 1972, s. 365, Fig.78: 69

o.

\section{SONUÇ}

Smintheion Büyük Roma Hamamı'nda 2008-2011 yılları arasında bulunan ve Geç Roma Dönemi'ne tarihlendirilen Afrika ve Phokaia damgalı seramikleri üzerine yapılan bu değerlendirme sonucunda beş adet örneğin Afrika, yirmi dört adet örneğin ise Phokaia üretimi olduğu tespit edilmiştir (Grafik 1). Çalışılan malzemenin sayıca az olmasıyla ters orantılı olarak bilinen Geç Roma seramikleri ile ilgili neredeyse tüm damga gruplarından bezeme örneklerinin bulunması, damga bezemelerinin Antik Çağ insanı tarafından sevilerek kullanıldığını göstermektedir. Yapılan kazı çalışmalarında Afrika ve Phokaia damgalıları dışında Kıbrıs ve Açık Renkli Geç Roma Dönemi damga bezemeli seramikleride ele geçmiştir. Ancak ele geçen bu parçalar gerek sayıca gereksede nitelik açısından yetersiz görüldügü için çalışmaya dahil edilmemiştir. Yapılan bu çalışmada sadece Afrika ve Phokaia damga bezemeli seramikleri üzerine bir değerlendirmeye gidilmiştir. 
Smintheion Büyük Roma... DEU Journal of GSSS, Vol: 22, Issue: 4

Grafik 1: Afrika ve Phokaia Damgalılarının Yüzdelik Dağılımı.

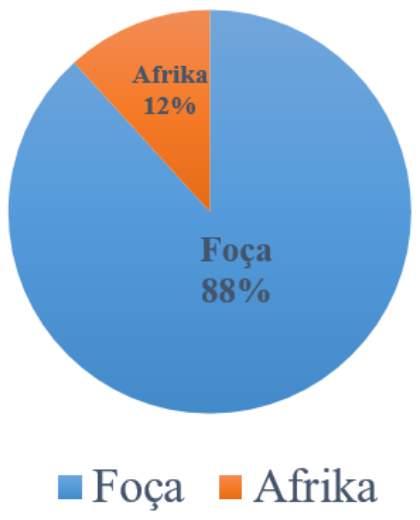

Metin içerisindeki değerlendirmelerimiz ve katalog bilgilerimizden de anlaşılacağı gibi Afrika ve Phokaia damgalılarının değerlendirilmesinde Hayes tarafından belirlenen gruplandırmadan yararlanılmıştır. $\mathrm{Bu}$ doğrultuda Afrika damgalıları beş ana stile (A-B-C-D-E) ve kendi içerisinde alt bölümlere ayrılmıştır (Hayes, 1972, ss. 217-219). Bu gruplandırma dikkate alındığında Afrika damgalıları içerisinde değerlendirilen beş adet örnekten (Kat. No. 1-5) bir tanesi A, bir tanesi D ve üç tanesi E stili içerisinde incelenmiştir. Kat. No. 1; A stilinin karakteristik bezemesi palmiye yaprağını taşımaktadır. Bunun yanında da iç içe geçmiş konsantrik daireler kullanılmıştır. D stili içerisinde incelenen Kat. No. 5'de Haç monogramı görülmektedir. ince nokta sıraları haç içerisinde tekrar etmektedir. Kat. No. 2-4 ise E (ii) stilinin özelliklerini taşımaktadır. Üç örnektede bezemelerin merkezi motif olarak tek başına kullanıldığ 1 görülmektedir. $\mathbf{2}$ numaralı örnekte merkezde bir kuzu, $\mathbf{3}$ numarada bir rahip ve $\mathbf{4}$ numarada haç kullanılmıştır.

Phokaia damgalıları toplam yirmi dört adet örnek ile incelemiş olduğumuz parçalar arasında en fazla bezeme çeşitliliğine sahip gruptur. Büyük Roma Hamamı kazısı sırasında ortaya çıkarılan Phokaia Geç Roma Dönemi seramikleri, form çeşitliliği ve sayıca da en fazla buluntu grubunu oluştururlar. Phokaia damgalılarında erken örneklerin düzenleme ve motif seçiminde Afrika damgalıları ile bir benzerlik görülmektedir. Damga bezemelerin genellikle merkezi bir motif olarak tek başlarına ya da tekrar eden motif bandı şeklinde kullanıldıkları bilinmektedir. Üç alt grupta (Grup I-II-III) incelenmiştir. Bu gruplandırmaya bakılarak incelenen örneklerden Kat. No. 6, Grup I içerisinde incelenmiş olup bünyesinde stilize edilmiş palmiye yapraklarını ve konsantrik daireleri barındırmaktadır. MS 360-450 arasına tarihlendirilmiştir. 7-11, 13, 17-18, 20, 22 ve 29 numaralı örnekler, Grup II içerisinde değerlendirilir ve üzerlerinde bitkisel, geometrik, hayvan ve haç damgaları taşırlar. Grup II içerisinde değerlendirilen bu örneklerin rulet ve yiv sıraları içerisinde tek başlarına ya da tekrarlanarak kullanıldıkları görülür. MS 440-490 arasına tarihlendirilmiştir. Son olarak 12, 14-16, 19, 21, 23-28 numaralı örnekler, Grup III 
içerisinde değerlendirilir ve geometrik, insan, hayvan ve haç damgaları kullanılmaktadır. Grup III'deki örneklerde bezemelerin daha büyük ve detaylı yapılmaya başlandığı görülür. Genellikle merkezde tek bir damga tamamlayıcı öge olarak kullanılır. Çok çeşitli bezemelerin yanında en yaygın kullanılanları haç ve haç monogramlarıdır. Bunu hayvan ve bitkisel motifler izler. İnsan figürleri görülmeye başlar. MS 470-580 arasına tarihlendirilmiştir. (Hayes, 1972, ss. 346-349).

Afrika ve Phokaia damgalılarının repertuar çeşitliliğine bakıldığında bunların; on tanesinin haç ve varyasyonlarına, sekiz tanesinin hayvan, beş tanesinin bitkisel, dört tanesinin geometrik ve iki tanesinin de insan damga bezemesi taşıdığ 1 görülmektedir (Grafik 2). Ele geçen örnekler 1şığında haç motiflerinin sayıca ilk sırada olduklarını görüyoruz. Bu durum Hristiyanlığın etkisiyle paganizmden çıkış arayışlarıyla açıklanabilir. Haç damgalı örnekleri dönemi gereği sevilerek tercih edilmiş ya da bir propaganda aracı olarak Hristiyanlığ 1 yaymak belki de popüleritesini arttırmak için kullanılmış olmalıdır. Sonuç olarak ticaret sayesinde gerek Phokaia gerekse de Afrika malları batıdan doğuya geniş bir coğrafi alana nüfuz etmiştir. Haç motifleri yanında doğadan yansımalarına şahit olduğumuz bitkisel ve hayvan motifleride önemlidir. Bu motifler çeşitli evreler içerisinde ele alınmış ve gelişimi bu evreler doğrultusunda değerlendirilmiştir. Her iki grup içerisindeki bezemelerde ortak noktalar vardır. Phokaia damgalılarında Afrika örneklerinin esintisini yakalamak mümkündür. Phokaia damgalıları bir nevi Afrika örneklerinin taklitleridir. Ancak zamanla bu benzerliğin yanında Phokaia'nın kendi üslubu olarak bazı bezemelerde yerel etkiler ve farkl1l1klar görülmeye başlayacaktır. Malzemenin çıkarıldığı kontekstle olan ilişkisine bakıldığında Büyük Hamam'ın kullanımının MS 4. yüzy1lın sonuna kadar sürdüğü ve bu tarihten sonra da hamam ve çevresinin konut ve işlik gibi farklı yapılara dönüştürüldüğü belirtilmektedir. Apollon Smintheion Kutsal Alanı'ndaki erken dönem yapıları incelendiğinde bunların tekrar tekrar kullanıldıkları ve zamanla yeni yapıların malzeme eksikliğinin giderilmesi için tahrip edildikleri bilinmektedir. Dönem şartları düşünüldügünde sosyal, siyasi ve ekonomik sıkıntıların baş gösterdiği zamanlarda hamam gibi büyük ve işletmesi masraflı yapıların kullanımı sekteye uğramış olmalıdır. Ayrıca kutsal alanda gerçekleşen bir Goth İstilasının varlığı, diğer tüm yapılar gibi hamamın da tahrip edilmiş olabileceğini göstermektedir. Bu tahribattan sonra da yapının aynı işlevinde ayağa kaldırılması zor gözükmektedir. Tüm bunlara bakılarak çalışılan malzemenin hamamın orijinal evresine ait olmadığ 1 yorumunu yapmak yanlış olmayacaktır. 
Grafik 2: Afrika ve Phokaia Damgalılarının Bezeme Repertuarı

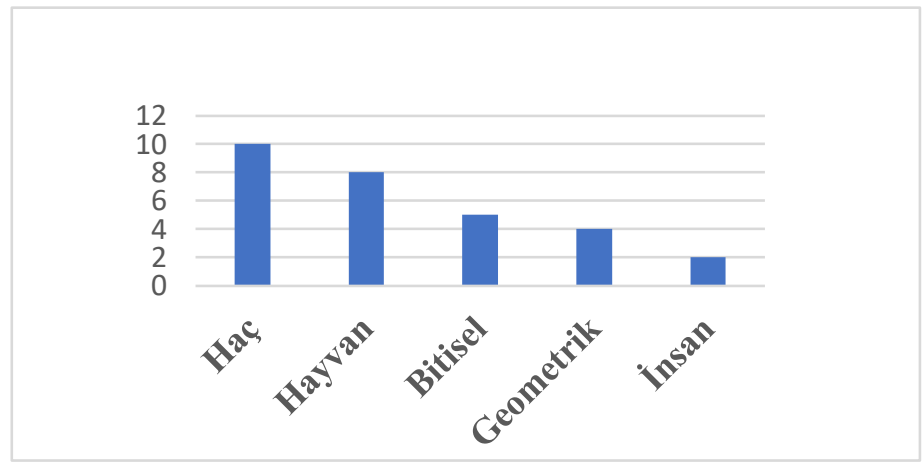

\section{KISALTMALAR}

Ed. Editör

Fig. Figür

Kat. Katalog

Ref. Referans

Tab. Tablo

\section{KAYNAKÇA}

Açar, E. (2017). Antandros Nekropolü Geç Roma yerleşimi. (Yayınlanmamış Yüksek Lisans Tezi). Ege Üniversitesi, Sosyal Bilimler Enstitüsü, İzmir.

Adıbelli, I. A. (2006). Tarsus Geç Roma seramiği. (Yayınlanmamış Geç Roma Seramiği). Ankara Üniversitesi, Sosyal Bilimler Enstitüsü, Ankara.

Aktaş, R. (2018). Antandros kazısı yamaç ev Roma dönemi seramikleri. (Yayınlanmamış Doktora Tezi). Ege Üniversitesi Sosyal Bilimler Enstitüsü, İzmir.

Aktaş, R. \& Sezgin, E. \& Çilingiroğlu, Ç. (2019). İzmir-Karaburun yüzey araştırmasında ele geçen Roma dönemi seramikleri, OLBA XXVII, 408-410

Ayaz. M. (2014). Asos Kuzey Stoası Kırmızı Astarl Roma Seramiği. (Yayınlanmamış Yüksek Lisans Tezi). Çanakkale Onsekiz Mart Üniversitesi, Sosyal Bilimler Enstitüsü, Çanakkale.

Смокотина, А. В. (2009). “Штампы На Ранневизантийской Краснолаковой Керамике Из Раскопок г. Боспора", "Stamps on the Early- 
Byzantine Red- Slip Wares from Excavations of the City of Bosporus", The Bosborus, Materials on the Archaeology, History and Ethnography of Tavria, Vol. XV, 163-171.

Doğer, L. (2007). Byzantine ceramics: Excavation at Smyrna Agora, B. Böhlendorf- Arslan, A.O. Uysal, J. Witte- Orr (eds.), Çanak, Akdeniz ve Çevresindeki Arkeolojik Kazılarda Ele Geçen Geç Antik ve Ortaçağ Seramiği ve Mimari Seramiği, Byzas 7, (ss. 97-122). İstanbul: Ege Yayınları.

Domzalski, K. (2012). At The Crossroads of trade Routes: terra sigillata, red slip wares and related fine pottery from the Polish excavations in Ptolemais (20022009), Ptolemais in Cyrenaica Studies İn Memory Of Tomasz Mikocki, University of Warsaw Institute of Archaeology, 337-341.

Domzalski, K. (2013). Terra Sigillata, red slip and glazed wares from Jiyeh (Porphyreon) and Chhim in Lebanon. similarities and differences in supplying coastal and mountain customers, Archeologia 64, 38-40.

Erol, D. (2011). Smyrna Agorasında ele geçen Terra Sigillata ve Geç Roma seramiği. (Yayımlanmamış Doktora Tezi). Dokuz Eylül Üniversitesi, Sosyal Bilimler Enstitüsü, İzmir.

Eiwanger, J. (1981). Keramik und Kleinfunde aus der Damokratia-Basilika in Demetrias, Demetrias IV, Teil 1.

Ergürer, E. (2012). Parion Roma Dönemi seramiği. (Yayınlanmamış Doktora Tezi). Atatürk Üniversitesi, Sosyal Bilimler Enstitüsü, Erzurum.

Ergürer, E. (2016), Parion Tiyatrosunda Bulunan Seramikler, (Ed. C. Başaran - E. Ergürer), Parion Roma Tiyatrosu, (ss. 139-141). İstanbul: İçdaş Yayınları.

Ergül, G. (2019). Parion Roma Hamamı 2014 y1lı kazı çalıșmalarından bir grup Geç Roma seramiği. Karamanoğlu Mehmetbey Üniversite Edebiyat Fakültesi Dergisi 2 (1). 44-56.

Fulford, M. G. \& Peacock, D. P. S. (1984). Excavations at Carthage: The British Mission Vol. 1, 2, The Pottery and Other Ceramic Object From The Site, London. Rome.

Hayes, J. W. (1972). Late Roman Pottery. London: The British School at

Hayes, J. W. (2008). Roman Pottery Fine-Ware Imports. The Athenian Agora. Vol. 32, New Jersey: The American School Of Classical Studies At Athens.

Hellström, P. (1965). Labraunda; Pottery of Classical and Later Date Terrecotta lamp and glass; Swedish excavations and researches, vol. II, part, 1. 
Heath, S. \& Tekkök, B. (2007-2008). Greek, Roman and Byzantine Pottery at Ilion (Troia), 2007-2008 Project Troia.

Johnson, B. L. (2008). Ashkelon 2: Imported Pottery of The Roman and Roman Periods, U.S.A: Harvard Semitic Museum Publications.

Kaplan, D. (2018). The Roman Baths and related structures / Smintheion Studies I. Ankara: Pozitif Matbaa.

Koçyiğit, O. (2013), Troas Bölgesi Geç Antik konut mimarlığ üzerine gözlemler, Sanat Tarihi Dergisi cilt: XXIV, Say1: 1, 152-153.

Mackensen, M. (1993). Die Spatantiken Sigillata und Lampentöpfereien von El Mahrine (Nord Tunusien). Studien Zur Nordafrikanischen Feinkeramik des 4. Bis 7. Jhr., Münchner Beitrage Zur Vor und Frühgeschischte, band 50, Münih.

Mackensen, M. \& Schneider, G. (2002). Production centres of African red slip ware (3rd-7th c.) in northern and central Tunisia: archaeological provenance and referance groups based on chemical analysis, Journal of Roman Archaeology Volume 15, 121-158.

Mimaroğlu, S. (2017). Myndos (Asar Adası) Geç Antik Dönem Seramikleri, Sanat Tarihi Dergisi 26 (2), 333-361.

Mocanu, M. (2012). Late Roman Fine Pottery with Stamped Decoration Discovered At (L?) İbida (Province of Scythia), Congressvs Vicesimvs Septimvs Rei Cretariæ Romanæ Favtorvm Singidvni Habitvs MMX (Ed. Susanne Biegert), (ss. 107-111), Rei Cretaarie Romane Favtorum Acta 42.

Opait, A. (2004). Local and imported ceramics in the Roman Province of Scythia (4th- 6th centuries AD), BAR- IS 1274, England: The Basingstoke Press.

Özgünel, A. C. (1982). Chryse-Apollon Smintheus Tapınağ 1980-1981 Y11 Kazıları, IV. Kazı Sonuçları Toplantısı, Ankara, 207-208.

Prieto, F. J. N. (1984). Algunos datas sobre las importaciones de ceramica 'Late Roman C' en la Peninsula İberica, Papers in Iberian Archaeology, BAR-IS 193 (ii), 540-548.

45.

Rautman, M. L. (1995). “Two Late Roman wells at Sardis”, AASOR 53, 44-

Reynal, C. A. \& Sodini, J. P. (1992). La Ceramique Paleochretienne De Thasos (Aliki,Delkos, Fouilles Ancinnes), Etudes Thasiennes XIII, Athens.

Sabine, L. \& Sauer, R. (2005). "Late Roman C-Ware und Lokale Spätantike Feinware aus Ephesos", Spätantike und mittelalterliche Keramik aus Ephesos, Wien: Verlag der Österreichischen Akademie der Wissenschaften, Band 13, 143-201. 
Şimşek, C. \& Bilgin, M. (2018). Leodikeia Geç Antik Çağ Seramikleri, Leodikeia Çalışmaları Ek Yayın Dizisi, Geç Antik Çăğ'da Lykos Vadisi ve Çevresi, Ege Yayınları, 181.

Topoleanu, F. (2003). "La Diffusion de la Ceramique D'Asie Mineure A Halmyris a L'Epoque Romaine Tardive: Importations et Imitations Locales", (Ed. Catherine Abadie- Reynal), Les Ceramiques en Anatolie aux Epoques Hellenistique et Romain:Varia Anatolica, XV. Paris, 209-217.

Tüzün, B. (1997). Alexandria Troas Yüzey Seramikleri. (Yayınlanmamış Yüksek Lisans Tezi). Ankara Üniversitesi, Sosyal Bilimler Enstitüsü, Ankara.

Uğuz, G. (2015). Phokaia'nın Kuzeyinde Geç Roma Dönemi bir Terra Sigillata atölyesi. (Yayımlanmamış Yüksek Lisans Tezi). Ege Üniversitesi, Sosyal Bilimler Enstitüsü, İzmir.

Waagé, F. O. (1933). "The American excavations in the Athenian Agora: First report”, Hesperia 2, No: 2, 297-299.

Waagé, F. O. (1948). "Hellenistic and Roman Tableware of North Syria", Antioch on the Orontes IV. Part One, Ceramic and Islamic Coins, New Jersey: Princeton University Press.

Williams, C. (1989). Anemurium the Roman and Early Byzantine Pottery, Pontifical Institude of Mediaeval Studies, Toronto: Pontifical Institute of Mediaeval Studies.

Yeşilova, H. (2007). Allianoi Antik Ilıcası Erken Bizans Dönemi Seramikleri (Kırmızı astarl kaplar ve günlük kullanım kapları, 1999-2005). (Yayınlanmamış Yüksek Lisans Tezi). Hacettepe Üniversitesi, Sosyal Bilimler Enstitüsü, Ankara.

Zhuravlev, D. V. (2002). "Terra Sigillata and Red Slip Pottery in the North Pontic Region (A short bibliographical survey)", Ancient Civilizations from Scythia to Siberia 8. 3- 4, 267. 